\title{
Article \\ Differential Regulation of Gonadotropins as Revealed by Transcriptomes of Distinct LH and FSH Cells of Fish Pituitary
}

\author{
Lian Hollander-Cohen ${ }^{1}$, Matan Golan ${ }^{2} \mathbb{D}$ and Berta Levavi-Sivan ${ }^{1, *(D)}$ \\ 1 Department of Animal Sciences, The Robert H. Smith Faculty of Agriculture, Food, and Environment, \\ Hebrew University of Jerusalem, Rehovot 76100, Israel; lian.hollander@mail.huji.ac.il \\ 2 Department of Poultry and Aquaculture, Institute of Animal Sciences, Agricultural Research Organization, \\ Volcani Center, P.O.B 15159, Rishon Letziyon 7505101, Israel; matang@volcani.agri.gov.il \\ * Correspondence: berta.sivan@mail.huji.ac.il
}

check for updates

Citation: Hollander-Cohen, L.; Golan, M.; Levavi-Sivan, B.

Differential Regulation of

Gonadotropins as Revealed by Transcriptomes of Distinct LH and FSH Cells of Fish Pituitary. Int. J. Mol. Sci. 2021, 22, 6478. https://doi.org/ $10.3390 /$ ijms 22126478

Academic Editor: Panagiotis

G. Anagnostis

Received: 11 May 2021

Accepted: 10 June 2021

Published: 17 June 2021

Publisher's Note: MDPI stays neutral with regard to jurisdictional claims in published maps and institutional affiliations.

Copyright: (c) 2021 by the authors. Licensee MDPI, Basel, Switzerland. This article is an open access article distributed under the terms and conditions of the Creative Commons Attribution (CC BY) license (https:/ / creativecommons.org/licenses/by/ $4.0 /)$.

\begin{abstract}
From mammals to fish, reproduction is driven by luteinizing hormone (LH) and folliclestimulating hormone (FSH) temporally secreted from the pituitary gland. Teleost fish are an excellent model for addressing the unique regulation and function of each gonadotropin cell since, unlike mammals, they synthesize and secrete LH and FSH from distinct cells. Only very distant vertebrate classes (such as fish and birds) demonstrate the mono-hormonal strategy, suggesting a potential convergent evolution. Cell-specific transcriptome analysis of double-labeled transgenic tilapia expressing GFP and RFP in LH or FSH cells, respectively, yielded genes specifically enriched in each cell type, revealing differences in hormone regulation, receptor expression, cell signaling, and electrical properties. Each cell type expresses a unique GPCR signature that reveals the direct regulation of metabolic and homeostatic hormones. Comparing these novel transcriptomes to that of rat gonadotrophs revealed conserved genes that might specifically contribute to each gonadotropin activity in mammals, suggesting conserved mechanisms controlling the differential regulation of gonadotropins in vertebrates.
\end{abstract}

Keywords: LH; FSH; pituitary; GPCR; gonadotropins; neuropeptides; cck; GnRH

\section{Introduction}

The gonadotropin hormones (GtHs), including luteinizing hormone (LH) and follicle stimulating hormone (FSH), are glycoproteins produced by the pituitary gland that are required for normal reproductive function and gonad development in vertebrates. As part of the hypothalamus-pituitary-gonad (HPG) axis, their expression and release are mainly regulated by hypothalamic gonadotropin-releasing hormone $(\mathrm{GnRH})$ and their effects on the gonads are distinct; FSH stimulates the growth of ovarian follicles in females and spermatogenesis in males, while LH induces ovulation in females and spermiogenesis in males [1,2]. The unique secretion pattern of each gonadotropin dictates the reproductive state of the organism and is crucial for maintaining a healthy reproductive state [3].

In mammals, both gonadotropins are secreted from a population of the same cell type, the gonadotroph. The differential secretion of each hormone is regulated by different hypothalamic and systemic hormones. GnRH is considered the main hormone known to directly stimulate differential GtH secretion. It is secreted in a pulsatile manner, where low-frequency GnRH pulses tend to release FSH and high-frequency GnRH pulses stimulate LH release [3,4]. Additional hormones that interact with GnRH signaling, like activin/inhibin, different feedback mechanisms involving gonadal steroids [5], and different autocrine/paracrine/juxtacrine pathways [6] were also shown to regulate the differential secretion of LH and FSH. In teleosts and mammals, it has been recently established that GnRH is part of an orchestra of different neuropeptides that together control the synthesis and release of FSH and LH [7,8]. Different hypothalamic neurohormones were shown to affect gonadotropin secretion like kisspeptin [9-13], neurokinin B (NKB) [14], LPXRFa 
peptide [9,15], spexin [16], and more, some of which suggest a direct regulation on the gonadotropic cells. Nevertheless, the exact cellular mechanism and hormone regulation that leads to the differential secretion and transcription of LH and FSH remain unknown.

Teleost fish are a particularly attractive model to dissect the differential regulation of GtH synthesis/secretion since, in contrast to mammals, LH and FSH are produced in discrete cell populations. We previously demonstrated the unique spatial organization in the fish pituitary gland of each cell type using transgenic tilapia expressing GFP in FSH cells and mCherry in LH cells $[17,18]$. LH cells exhibit close cell-cell contacts and form a continuous network throughout the gland, while FSH cells were more loosely distributed but maintained some degree of cell-cell contact by virtue of cytoplasmic processes. The unique spatial distribution of these cell types had also manifested functional differences like gap-junction potentiation of LH secretion across the population of cells in response to GnRH [17].

We took advantage of these discrete LH and FSH populations in teleosts to reveal the transcriptional basis underlying their differential secretion. Using transgenic tilapia with fluorescent-labeled gonadotrophs, we performed RNA-seq on purified LH and FSH cells from the pituitaries of transgenic males and females. We found distinct genes which are enriched in each cell type and reveal new candidates that may directly regulate LH or FSH and different cellular pathways that are unique to each GtH cell type. We also identified conserved genes between mammals and teleosts that specifically regulate $\mathrm{LH}$ or FSH cell activity by comparing the fish cell specific gene expression to that of the rat gonadotroph, thereby identifying genes that may suggest functions which are unique to each hormone, allowing them to be synthesized/secreted in a differential manner while being regulated by the same GnRH hormone and secreted from the same cell.

\section{Results and Discussion}

\subsection{The Emergence of the Mono-Hormonal System from Bi-Hormonal Gonadotrophs}

The pituitary gland is a vertebrate novelty and is derived from the adenohypophyseal neurogenic placode [19]. Among different taxa and classes there are significant variations in the organization of the gonadotropic cells in the pituitary gland (Figure 1). In lampreys, an ancient jawless fish, the pituitary contains a proto-glycotrope secreting two hormones: thyrostimulin and only one glycoprotein hormone [20-22]. Although cartilaginous fishes possess two gonadotropins [23], their cellular distribution is unknown. Two different morphological phenotypes of gonadotrophs emerged in later evolved vertebrates, with some lineages evolving bi-hormonal cells (one cell secreting both LH and FSH: amphibians, reptiles, and mammals) and some evolving mono-hormonal cells (two cells secreting each a different gonadotropic hormone: teleost and avian). It is very tempting to think that this phenomenon will have an evolutionary common origin, but it seems that this is a case of convergent evolution since only two very distant vertebrate classes demonstrate the mono-hormonal strategy: teleosts [1] and birds [24] (Figure 1). 


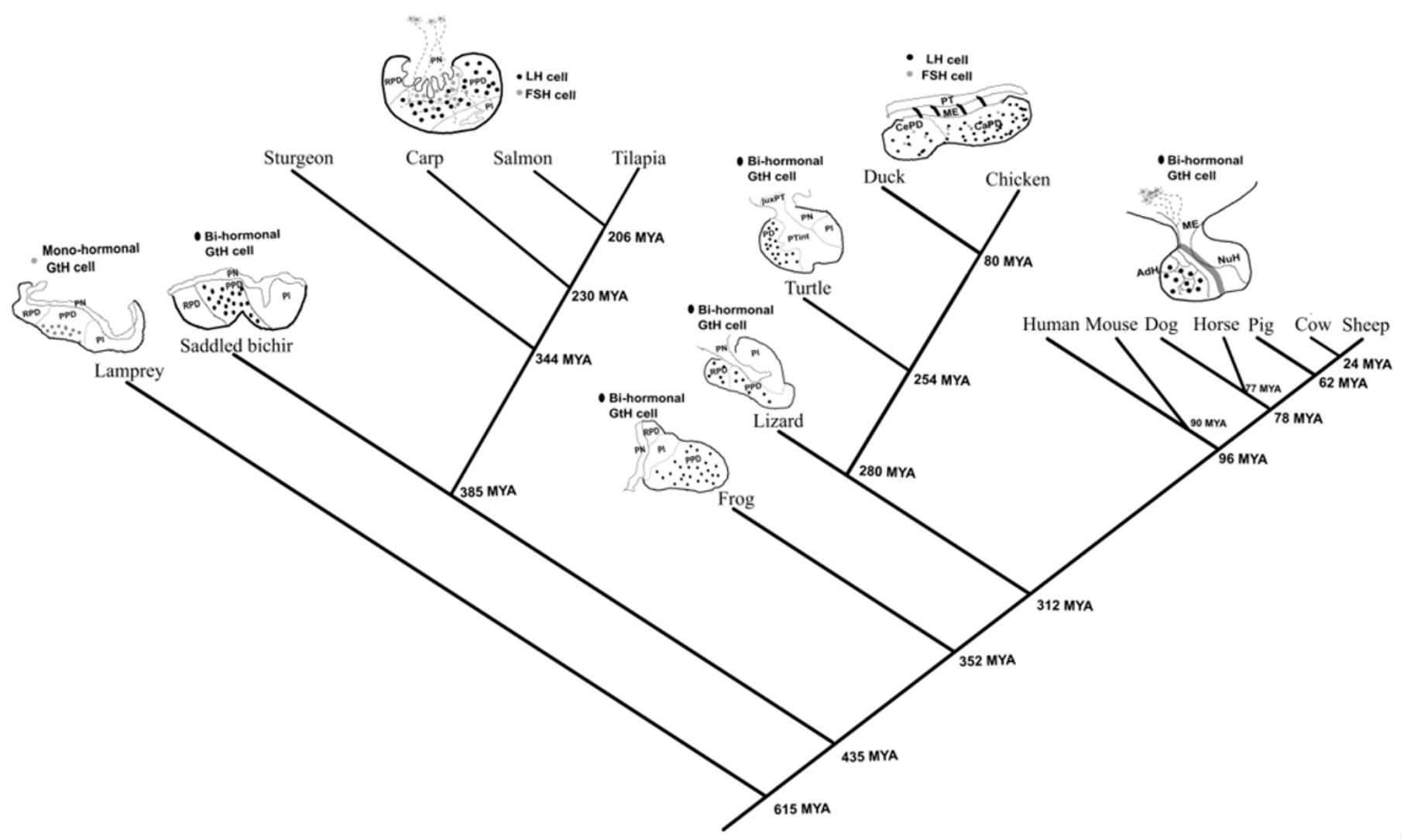

Figure 1. Taxonomic tree of representative vertebrate taxa showing differences in morphology and gonadotroph organization. The distribution of FSH and/or LH cells in the vertebrate pituitary is either bi-hormonal (one cell expressing both gonadotropins), or mono-hormonal cells (two cells secreting each a different gonadotropic hormone). An exception is the proto-glycotrope expressing only one gonadotropic hormone that exists in lamprey. From the different taxa, only the teleost and avian exhibit the mono-hormonal cell morphology while mammals, reptiles, and amphibians exhibit the bi-hormonal morphology. The taxonomic tree was prepared using TIMETREE [25] and visualized with the pituitary diagrams using Inkscape. The evolutionary tree includes only organisms with known information regarding their $\mathrm{GtH}$ distribution in the pituitary. Information regarding each organism was obtained from: Mouse (Mus musculus) [26,27], dogs (Canis lupus familiaris) [28], pigs (Sus scrofa domesticus) [29], human (Homo sapiens) [30], sheep (Ovis aries) [31], horse (Equus ferus caballus) [32], cow (Bos Taurus) [33], lamprey (Petromyzon marinus) [34], Saddled bichir (Polypterus endlicherii) [35], tilapia (Oreochromis niloticus) [17], carp (Cyprinus carpio) [36], salmon (Salmo salar) [37], sturgeon (Acipenser gueldenstaedtii) [38], turtle (Geoclemys reevesii) [39], chicken (Gallus gallus) [24], duck (Anas acuta) [40], lizard (Calotes versicolor) [41], and frog (Rana japonica) [42]. Rostral pars distalis (RPD), proximal pars distalis (PPD), pars intermedia (PI), pars nervosa (PN), pars distalis (PD), juxtaneural pars tuberalis (juxPT), pars tuberalis interna (PTint), pars tuberalis (PT), median eminence (ME), cephalic pars distalis (CePD), caudal pars distalis (CaPD), adenohypophysis (AdH), neurohypophysis $(\mathrm{NuH})$.

Interestingly, both mono-hormonal classes have evolved from bi-hormonal classes. In teleosts, it seems that the mono-hormonal system had evolved somewhere in the course of the actinopterygian radiation, as a fish from the polypteridae (Sadddled bichir), a basal family in this class, contain bi-hormonal morphology while a fish from the more advanced acipenseridae family in this class (Sturgeon) exhibit the mono-hormonal morphology, suggesting that the mono-hormonal system might be present in fish that do not belong to the teleost order. Unfortunately, no evidence regarding the gonadotrophs morphology exists in other fish orders except the ones mentioned in Figure 1.

How this unique change in the cell morphology contributes to the reproductive strategy and functionality of these classes via the HPG axis is an enigma. We can speculate that the evolutionary pressure for the segregation of those two cells is either due to a unique functionality of LH or FSH in those organisms or a unique regulatory process of their activity, directly linking between reproduction and different metabolic processes like 
growth, feeding and homeostasis. Since LH activity in vertebrates is well characterized and essentially conserved $[43,44]$, we suspect that FSH might exhibit an unknown regulatory activity which is unique to teleosts. By revealing conserved genes between a monohormonal and a bi-hormonal organism, we were able to contemplate which of the functions identified in each cell type had a common source and which had uniquely evolved within the mono-hormonal system, thereby establishing the basis for understanding the unique functionality and regulation of each hormone in the different lineages.

\subsection{The Isolation of LH and FSH Cells}

Confocal imaging of double-labeled pituitary expressing RFP in LH cells and GFP in FSH cells confirmed the expression of the fluorophores in the proximal pars distalis (PPD), (Figure 2A) where each fluorophore was expressed exclusively in different cell types. FSH cells are located dorsally to the LH cells closer to the dorsal projections of the pars nervosa (PN) and both cell types are distributed from the ventral to the posterior side of the pituitary as was shown before for mono-labeled transgenic fish [17,45]. Even though fish pituitary morphology is very distinct, its development, major compartments, and functions within the HPG axis are well conserved with other vertebrates [46,47].

A

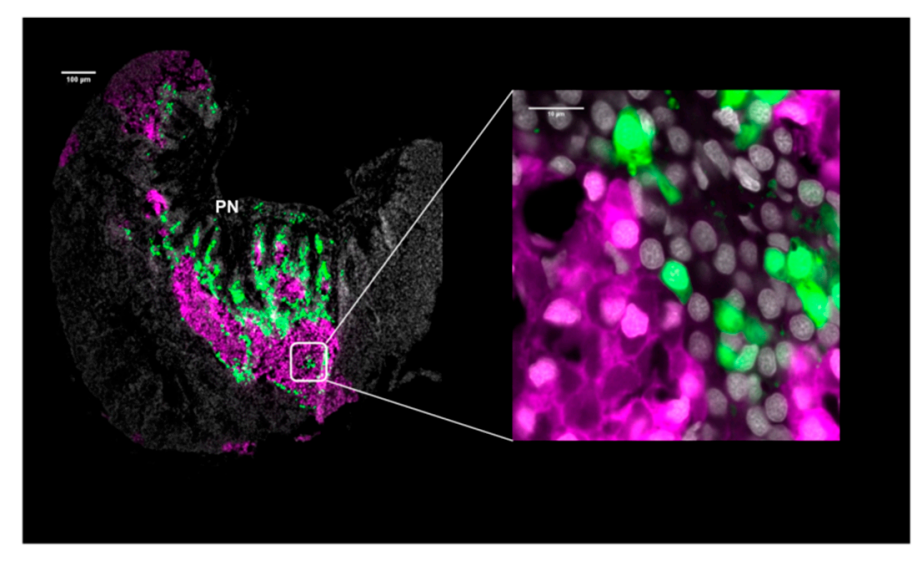

C

\begin{tabular}{|c|c|c|c|c|c|c|c|c|c|}
\hline & & \multicolumn{2}{|c|}{ Sample 1} & \multicolumn{2}{|c|}{ Sample 2} & \multicolumn{2}{|c|}{ Sample 3} & \multicolumn{2}{|c|}{ Sample 4} \\
\hline & & $\begin{array}{l}\text { \# of cells } \\
\text { collected }\end{array}$ & $\begin{array}{l}\mathrm{RNA} \\
\mathrm{ng} / \mathrm{uL}\end{array}$ & $\begin{array}{l}\text { \# of cells } \\
\text { collected }\end{array}$ & $\begin{array}{l}\text { RNA } \\
\mathrm{ng} / \mathrm{uL}\end{array}$ & $\begin{array}{l}\text { \# of cells } \\
\text { collected }\end{array}$ & $\begin{array}{c}\text { RNA } \\
\mathrm{ng} / \mathrm{uL}\end{array}$ & $\begin{array}{l}\text { \# of cells } \\
\text { collected }\end{array}$ & $\begin{array}{l}\text { RNA } \\
\mathrm{ng} / \mathrm{uL}\end{array}$ \\
\hline \multirow{4}{*}{ Female } & GFP & 55,000 & 2.67 & 40,000 & 1.9 & 40,000 & 1.34 & 46,000 & 1.33 \\
\hline & RFP & 55,000 & 1.81 & 40,000 & 2.21 & 36,045 & 1.85 & 39,647 & 1.13 \\
\hline & NEG & 55,000 & 1.81 & 40,000 & 2.07 & 38,010 & 1.88 & 46,000 & 1.88 \\
\hline & Before & & 18.8 & & 20 & & 9.33 & & 1.08 \\
\hline \multirow{4}{*}{ Male } & GFP & 43,951 & 4.3 & 40,388 & 2.23 & 33,432 & 2.14 & 50,000 & 3.15 \\
\hline & RFP & 39,837 & 3.2 & 23,397 & 1.84 & 26,213 & 1.24 & 50,000 & 1.9 \\
\hline & NEG & 60,000 & 3.1 & 40,000 & 1.6 & 42,313 & 0.973 & 50,000 & 1.74 \\
\hline & Before & & 49 & & 7 & & 16.5 & & 12.9 \\
\hline
\end{tabular}

B
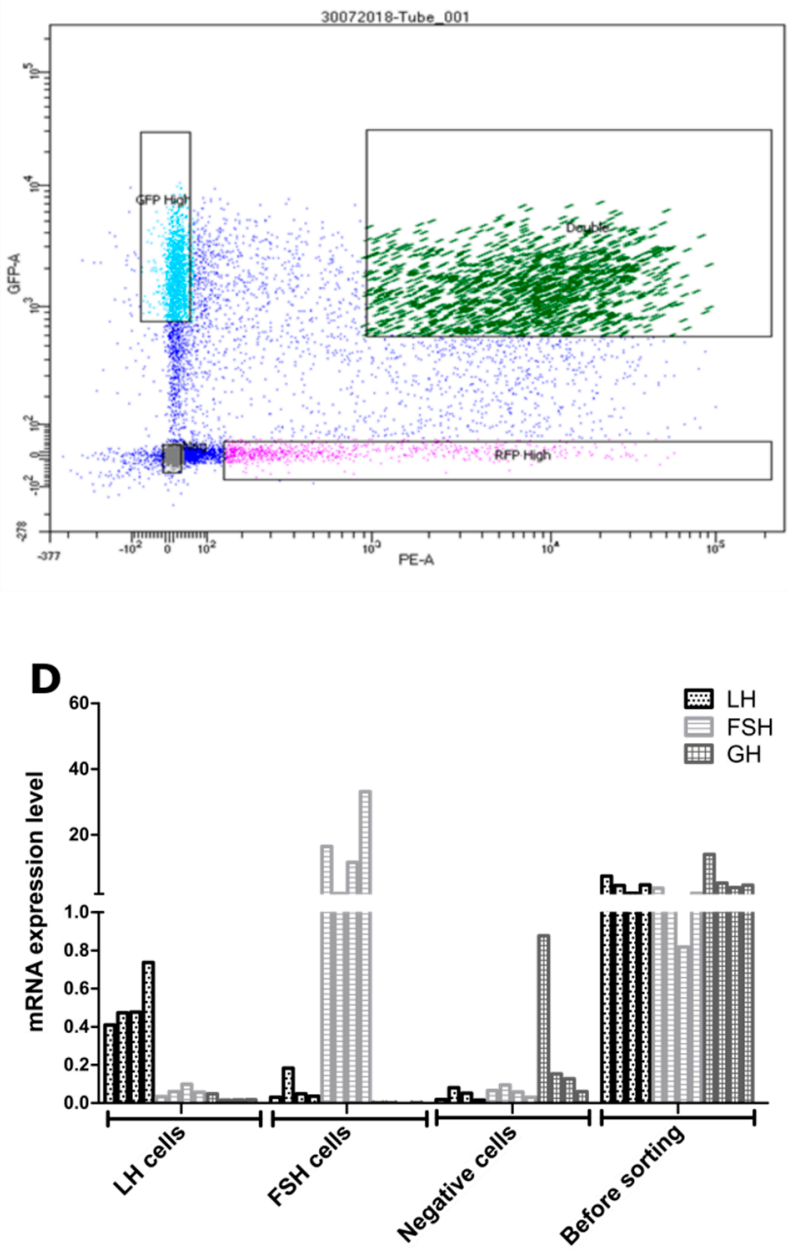

Figure 2. LH and FSH cells isolated from transgenic tilapia expressing double labeled pituitaries. (A) Confocal imaging of a double-labeled pituitary slice from mature transgenic Nile tilapia expressing RFP (magenta) under the regulation of LH promotor and GFP (green) under the regulation of FSH promoter. The right image contains a 60x magnification of the marked square in the left image revealing each hormone is expressed in a different cell. DAPI is used for visualizing the cell's nucleus (gray). (PN) Pars nervosa. Scale bar: $100 \mu \mathrm{M}$ and $10 \mu \mathrm{M}$. (B) Scatter plot showing separation between GFP and RFP marked cells of the FACS assayed cells that were collected from the double labeled pituitaries. In each FACS assay four 
fractions were collected: GFP high- FSH positive cells, RFP high- LH positive cells, double-RFP and GFP positive cells, and negative-all non-LH or FSH pituitary cells. For each FACS assay, between 16 and 21 pituitaries were collected and each assay was repeated four times for each sex. The gonadosomatic index of fish used for each assay is detailed in Supplementary Figure S1. The complete gating parameters of the FACS assays are available in Supplementary Figure S2. (C) The number of collected cells and the amount of RNA extracted from each fraction of the FACS cells. (D) Real-time PCR validation of lhb, fshb, and gh in the "before" and "after" FACS fractions revealing LH and FSH enrichment in each fraction respectively, each line representing a FACS fraction $(n=1)$. Values were normalized against the reference gene EF1 $\alpha$ using the comparative threshold cycle method $(-\Delta C T)$. The primer sequences used for real-time PCR are available in Supplementary Table S1.

In order to achieve specific separation of LH or FSH expressing cells, we used FACS to sort the double labeled pituitaries. Four fractions of cell populations were collected (Figure 2B): GFP-positive FSH cells only, RFP-positive LH cells only, negative (nonfluorescent) cells, and RFP and GFP positive double-labeled cells. The double-labeled fraction was not subjected to any further analysis since it probably contained doublets of LH and FSH cells. The sorting was performed four times for male pituitaries and four times for female pituitaries, where each fraction contained between 23,397 to 60,000 cells and extracted between $0.97 \mathrm{ng} / \mu \mathrm{L}$ to $4.3 \mathrm{ng} / \mu \mathrm{L}$ total RNA (emerging from 16-20 pituitaries/batch/sex) (Figure 2C). Before each FACS procedure, a sample of $100 \mu \mathrm{L}$ from the cell solution was collected, which yielded between $1.08 \mathrm{ng} / \mu \mathrm{L}$ to $49 \mathrm{ng} / \mu \mathrm{g}$ total RNA (Figure $2 \mathrm{C}$ ). Real-time PCR validation of $\mathrm{LH} \beta$ subunit $(\operatorname{lh} \beta), \mathrm{FSH} \beta$ subunit $(f \operatorname{sh} \beta)$, and growth hormone $(g h)$ revealed that the cells were successfully separated (Figure 2D), as their corresponding hormones were enriched in the respective fractions. $\mathrm{GH}$, a highly expressed pituitary hormone [27,48], was expressed only in the negative fraction and in the fraction that contained cells before sorting where all pituitary hormones are expressed. We can therefore conclude that our sorting strategy generated highly enriched LH and FSH cell fractions that allowed us to confidently attribute the molecular signature revealed by the transcriptome analysis to a specific cell population.

\subsection{Identifying Enriched Genes in Both FSH and LH Cells}

To identify the enriched genes (EG) in each cell type, we compared the expression of genes in each gonadotroph library to the negative library. Due to the high number of genes expressed in LH and FSH cells, we only investigated the genes that are enriched in each gonadotroph type compared to the rest of the cells in the pituitary; therefore genes that are common to LH or FSH and might also be expressed in other cell types are not discussed in the current work. The fold change expression of nine known genes of pituitary hormones were validated (Figure $3 \mathrm{~A}$ ); lh $\beta$, fsh $\beta$, glycoprotein $\alpha$-subunit $(g c \alpha)$, gh, two isoforms of prolactin $(\operatorname{prl}(1)$ and $\operatorname{prl}(2))$, thyroid-stimulating hormone $(t s h \beta)$, somatolactin $(s l)$, and pro-opiomelanocortin (pomc). LH and FSH cells fractions were enriched specifically with their cognate hormones ( $\operatorname{lh} \beta$ and $f \operatorname{sh} \beta$, respectively) and the rest of the hormones were highly expressed in the negative fraction.

In addition, three genes had higher expression in the gonadotrophs fractions compared to the negative fraction: $\operatorname{cg} \alpha, p o m c$, and $s l$. As expected, the $\operatorname{cg} \alpha$ of the heterodimeric hormones LH and FSH was also enriched in the LH and FSH fraction-but to a lower extent, probably due to the fact that it is also a part of the heterodimeric glycoprotein hormone TSH which is highly expressed in the negative fraction. Surprisingly, pomc and $s l$ have low fold change expression in the LH fraction; both hormones are complex and less studied in the pituitary glands of teleosts. Pomc encodes multiple neuropeptides and has three different subtypes in teleost $[49,50]$. The $s l$ gene is identified only in fish and some amphibians [51], and exhibits different functions in different fish species [52]. Their low expression can be either due to small contamination of these cells in this fraction or an endogenous expression of the hormone in these cells. In order to reduce the chance of cross-contamination, only genes that had a fold change higher than 2 were used in the 
clustergram analysis to identify EGs in the gonadotroph, thereby ensuring the elimination of genes from unwanted cells contamination in the FACS procedure.

\section{A}

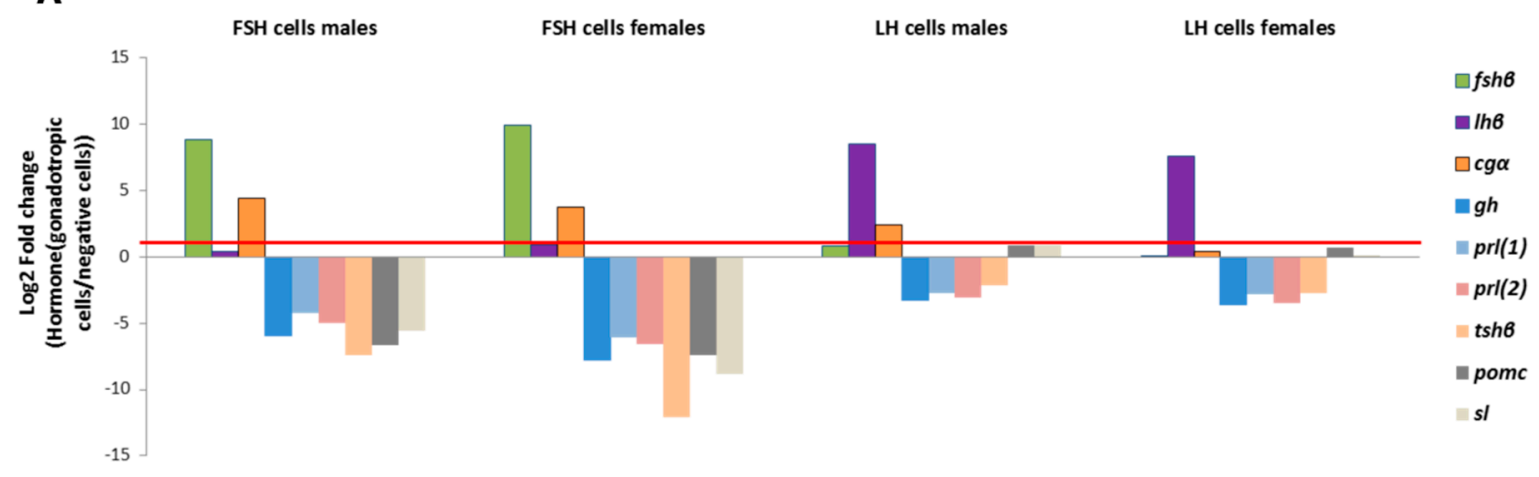

B

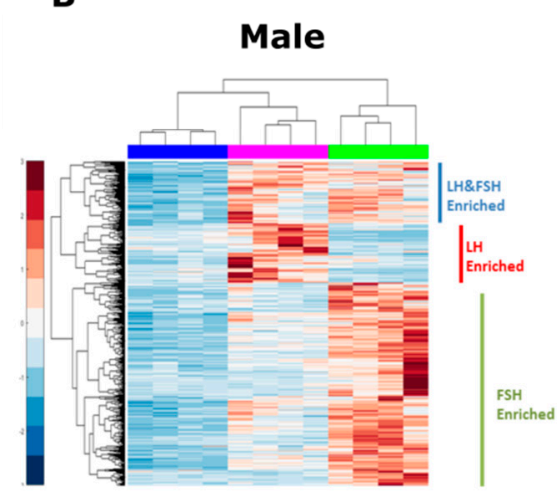

C

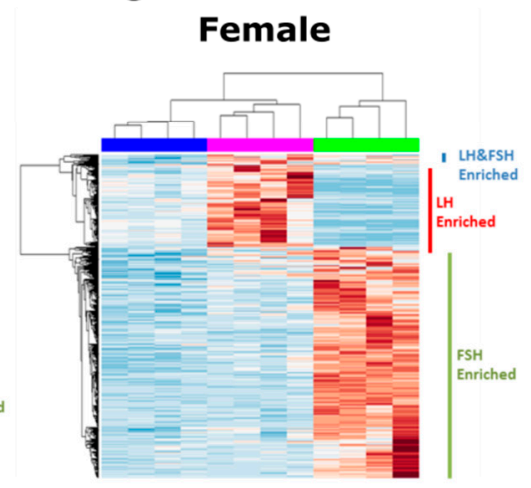

D

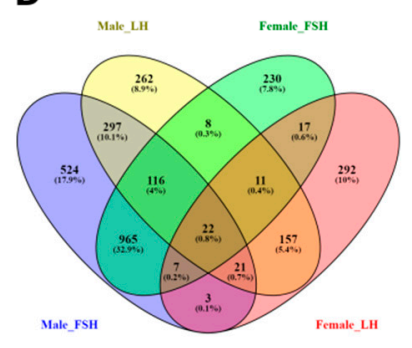

Figure 3. Identifying differentially expressed genes in LH and FSH cells. (A) The fold change (represented in log2) of normalized reads of the common pituitary hormone genes in the sorted fractions, as expressed in the RNA-seq libraries. Values are compared to the negative cells fraction. Positive values represent genes enriched in LH and FSH cells and negative values represent genes enriched in the negative cell fraction. Supplementary Table S2 details the exact fold change values for each hormone in each fraction and the gene id for each hormone. As predicted, each hormone (the beta subunits $\operatorname{lh} \beta / \mathrm{fsh} \beta$ together with the common alpha subunit, $\operatorname{cg} \alpha$, which constructs the complete mature hormones) is highly enriched in its own cell type and no other hormone contains a significant expression value in the gonadotrophs. In order to ensure that only LH or FSH cells specific genes are analyzed in each relevant fraction, we filtered for genes with a fold change greater than $2\left(\log _{2}(1)\right.$, represented by the red line) for the cluster analysis. $(\mathbf{B}, \mathbf{C})$ Clustergram analysis of normalized reads (FDR corrected $p<0.05, \log _{2}$ (Fold change) $>1$ ) in LH, FSH, and negative fractions in each repeat $(n=4)$ in males $(\mathbf{B})$ and females (C). Each repeat from the same fraction was clustered together (top dendrogram). Three main clusters of expressed genes were observed in each clustergram (left dendrogram); genes that were enriched in LH fraction, genes that were enriched in FSH fraction and genes that were enriched in LH and FSH fractions. All the genes used for the clustergram analysis and their values are publicly available in GEO (ID:GSE159470). (D) Venn diagram combining the male and female clustergram results, representing the number of enriched genes in each cluster and in each sex revealing high number of genes that are either cell specific or sex specific and only 22 genes that are common to all. The diagram was created using Venny_2.1 (https://bioinfogp.cnb.csic.es/tools/venny/) (accessed on 24 September 2019).

Clustergram analysis of the EGs (Fold change $>2$, false discovery rate (FDR) corrected $p<0.05)$ showed a clear separation between the different cell types in male and female (Figure 3B,C, respectively) where the experimental repeats of each cell type were clustered together. We categorized the genes in each sex into three groups: enriched in LH cells, enriched in FSH cells, and enriched in both cell types. In total, males exhibit 1499, 438, and 456 genes uniquely enriched in FSH, $\mathrm{LH}$, and both cell types respectively, and females exhibit 1319, 473, and 57 genes uniquely enriched in FSH, LH, and both cell types, respec- 
tively. In both sexes, the FSH group has higher number of enriched genes suggesting that FSH cells differ more from the rest of the pituitary cells.

In a Venn diagram combining the distribution of EGs in the different sexes and cell types (Figure 3D), the FSH fraction had more shared genes between the different sexes (965 shared genes vs. 524 and 230 genes uniquely expressed in males and females, respectively) compared to the $\mathrm{LH}$ fraction, which exhibits more unique genes in each sex (292 genes in females and 262 genes in males while only 157 genes are common to both), suggesting that LH cells are more sex-specific than FSH cells. Moreover, the sex- and cell-specific enriched genes can give us a clue regarding the factors that elicit LH-specific or FSH-specific regulation.

\subsection{Functional Annotation of Enriched Genes in LH and FSH}

Functional analysis performed on the specifically enriched genes of LH or FSH cells (Figure 4) revealed that the gene ontology (GO) annotations containing the highest amount of functions are common to both LH and FSH cells, supporting the hypothesis that the cells shared a common ancestor, while the different gene repertoires in each cell reveals different mechanisms that allowed for the differential transcription/secretion of each GtH.

The most enriched GO clusters in both cell types are related to channels and ion regulation (like "transporter activity", "ion channel activity", "cell-cell signaling" and "plasma membrane"). The excitability of gonadotropic cells and other endocrine cells in the pituitary have been extensively studied over the years [16,53-58]. The electrical activity of the gonadotrophs is considered the key factor for the episodic and synchronized activity of those cells [59]. Since most of the studies have been conducted in mammals (where both gonadotropins are secreted from a common cell), the exact electrical properties that differentially regulate LH or FSH secretion and expression remain elusive. In fish, even less is known regarding the different electrical properties of LH and FSH. Different electrical properties between LH and FSH cells have been shown in Atlantic cod (Gadus morhua) dispersed pituitary cells, where each cell exhibit different voltage depended current and tail current (KCa) profiles [58]. Additionally, LH and FSH cells exhibit different calcium responses to $\mathrm{GnRH}$ stimulations in an intact pituitary and brain preparation of medaka [60]. In our transcriptome analysis, different types of voltage gated channels and calcium channels are enriched in each cell type suggesting different excitability properties regulating $\mathrm{LH}$ and FSH.

Additional GO annotation of the enriched genes relates to internal signaling pathways and hormone packaging, (like "binding" and "protein binding") that include genes that relate to the activity of intracellular proteins like SNARE and GTPase. Interestingly in those GO annotations, each cell is enriched with a unique set of genes. GO annotations that relate to internal signaling pathways ("signal transducer activity") of hormones and steroid stimuli and GO annotations that include vesicle formation and transport activity ("intracellular"), most of them are highly enriched mainly in FSH cells revealing how those mechanisms are diverse in FSH cells.

\subsection{Highly Enriched Genes in LH and FSH Cells}

By looking at the 10 most enriched genes (EG) in each cell type (Table 1), unique genes that are expressed in each gonadotroph highlighted different functions that might be unique to each. The two most enriched genes are, not surprisingly, the associated gonadotropic hormone of each cell: $\operatorname{lh} \beta$ in LH cells (Males $\log 2$ (fold change) $=7.6$, Females $\log 2($ fold change $)=8.5$ ) and $f_{s h} \beta$ in FSH cells (Males $\log 2$ (fold change $)=8.84$, Females $\log 2$ (fold change) $\left.=9.91\right)$. 


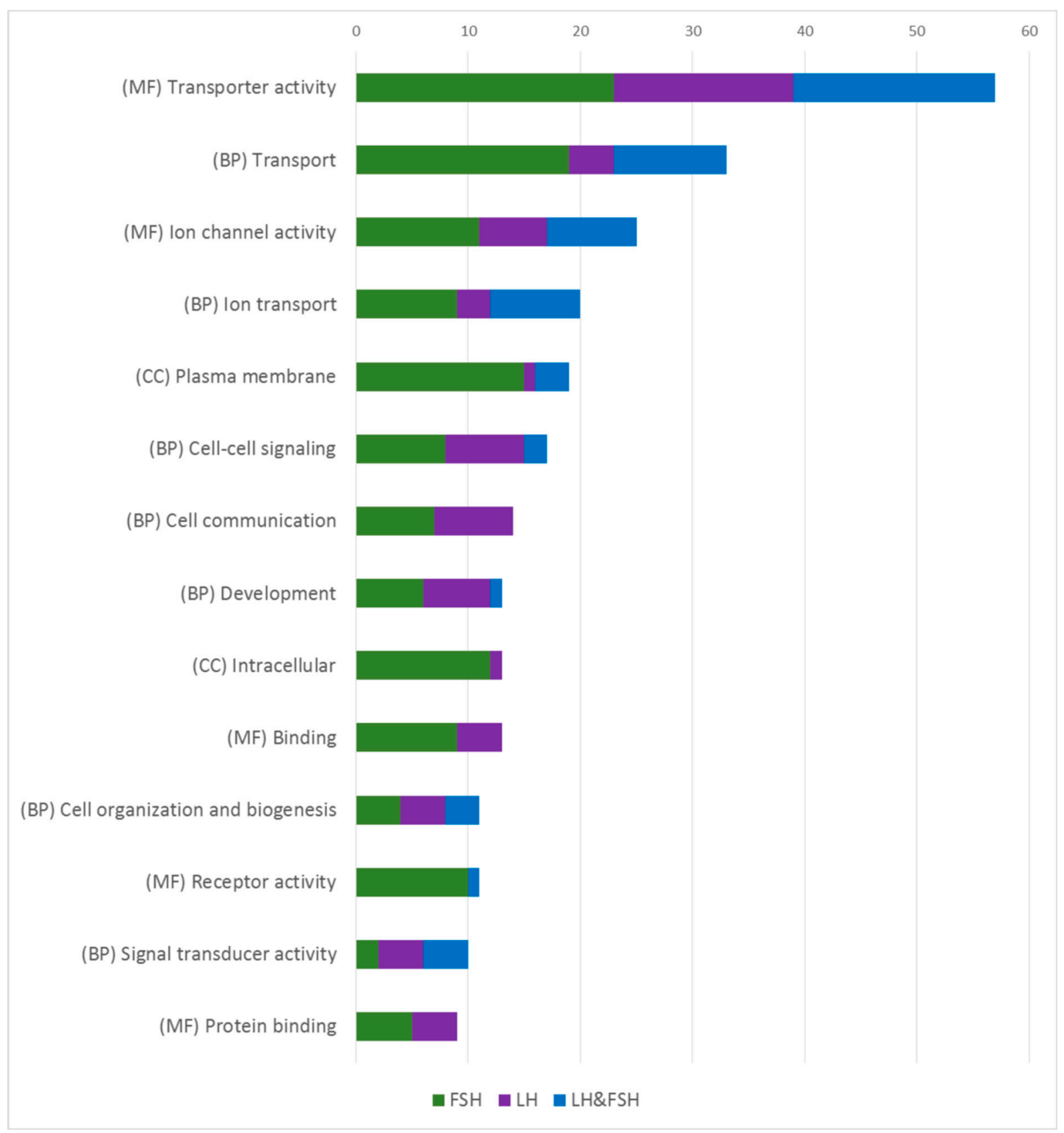

Figure 4. Functional enrichment analysis of enriched genes in each cell type and sex. Categorized GO annotation of functional enrichment analysis of the EG in males and females that were obtained from the clustergram analysis (Figure 2B,C). Values represent the number of GO annotations in each GO group, as each GO group represents the sum of GO annotations in males and female for each fraction (FSH in green, $\mathrm{LH}$ in purple, and FSH and LH in blue). The most substantial GO groups are common to both cell types while some express the same genes (blue) and some express genes which are unique to each cell type (FSH in green and LH in purple) revealing how similar LH and FSH cells are in their ontology, and how each cell type acquires its own unique processes to establish their unique functionality. Functional enrichment was performed with GO annotations of molecular functions (MF), biological processes (BP), and cellular component (CC). The exact procedure is detailed in the methods (Section 3.7). 
Table 1. Top 10 upregulated genes according to fold change in FACS sorted cells. Genes were grouped according to suggested function classification. Each gene is one of the top 10 genes in one or more of the different FACS samples as mentioned in the "TOP 10" column. Some of the genes are also enriched in additional samples but not included in their top 10 genes as mentioned in the "upregulated also in" column. See Supplementary Table S3 for fold change and expression values of each gene in each fraction.

\begin{tabular}{|c|c|c|c|c|}
\hline & Name & Protein Name & TOP 10 & Up Regulated Also In \\
\hline \multirow{4}{*}{$\begin{array}{l}\text { Gonadotrophs } \\
\text { secretion }\end{array}$} & $f \operatorname{sh} \beta$ & follitropin subunit beta isoform $\mathrm{X} 1$ & $\mathrm{FSH}(\mathrm{M} \& \mathrm{~F})$ & non \\
\hline & $\ln \beta$ & gonadotropin subunit beta-2 & LH(M\&F) & non \\
\hline & esr2 & estrogen receptor beta isoform $\mathrm{X} 2$ & \multicolumn{2}{|c|}{ LH\&FSH(M\&F) } \\
\hline & $p g r$ & progesterone receptor & $\mathrm{LH}(\mathrm{F})$ & $\mathrm{LH}(\mathrm{M})$ \\
\hline \multirow{2}{*}{$\begin{array}{l}\text { Neuroactive ligand } \\
\text { receptor interaction }\end{array}$} & $c c k r$ & cholecystokinin receptor & FSH(M\&F) & LH (M\&F) \\
\hline & apln & apelin & $\mathrm{LH}(\mathrm{M})$ & $\begin{array}{c}\text { FSH(M) } \\
\text { LH\&FSH(F) }\end{array}$ \\
\hline \multirow[t]{2}{*}{ Cell signaling } & pdeh6h & $\begin{array}{c}\text { retinal cone rhodopsin-sensitive cGMP } \\
3 \backslash^{\prime}, 5 \backslash^{\prime} \text {-cyclic phosphodiesterase subunit } \\
\text { gamma }\end{array}$ & FSH(M\&F) & \\
\hline & pcp4 & calmodulin regulator protein $\mathrm{PCP} 4$ isoform $\mathrm{X} 3$ & LH(M) FSH(F) & $\mathrm{FSH}(\mathrm{M}) \mathrm{LH}(\mathrm{F})$ \\
\hline \multirow{4}{*}{ Cell morphology } & xirp2 & $\begin{array}{l}\text { xin actin-binding repeat-containing protein } 2 \\
\text { isoform } \mathrm{X} 1\end{array}$ & $\mathrm{FSH}(\mathrm{F})$ & $\mathrm{FSH}(\mathrm{M}) \mathrm{LH}(\mathrm{F})$ \\
\hline & thbs $4 b$ & thrombospondin-4-B & LH(M\&F) & \\
\hline & $\operatorname{col} 5 a 2$ & collagen alpha-2(V) chain & $\mathrm{LH}(\mathrm{F})$ & $\mathrm{FSH}(\mathrm{F}) \mathrm{LH}(\mathrm{M})$ \\
\hline & cdh16 & cadherin-16 & $\mathrm{FSH}(\mathrm{F})$ & FSH(M) \\
\hline \multirow{4}{*}{$\begin{array}{l}\text { Post translation } \\
\text { modification }\end{array}$} & ndst4 & $\begin{array}{l}\text { bifunctional heparan sulfate } \\
\mathrm{N} \text {-deacetylase/N-sulfotransferase } 4 \text { isoform } \mathrm{X} 1\end{array}$ & $\mathrm{LH}(\mathrm{M})$ & $\mathrm{FSH}(\mathrm{M} \& \mathrm{~F}) \mathrm{LH}(\mathrm{F})$ \\
\hline & dclk3 & $\begin{array}{l}\text { serine/threonine-protein kinase DCLK3 } \\
\text { isoform } \mathrm{X} 1\end{array}$ & LH(M) & $\begin{array}{c}\mathrm{FSH}(\mathrm{M}) \\
\mathrm{LH} \& \mathrm{FSH}(\mathrm{F})\end{array}$ \\
\hline & pcdstpk & $\begin{array}{c}\text { probable cyclin-dependent } \\
\text { serine/threonine-protein kinase } \\
\text { DDB_G0292550 }\end{array}$ & $\mathrm{LH}(\mathrm{M} \& \mathrm{~F})$ & \\
\hline & tyr & tyrosinase & $\mathrm{FSH}(\mathrm{M})$ & \\
\hline \multirow{3}{*}{ Protein trafficking } & tnfaip2 & tumor necrosis factor alpha-induced protein 2 & $\mathrm{FSH}(\mathrm{M} \& \mathrm{~F})$ & \\
\hline & tnfaip2 & tumor necrosis factor alpha-induced protein 2 & FSH(M\&F) & \\
\hline & tnfaip2 & tumor necrosis factor alpha-induced protein 2 & $\mathrm{FSH}(\mathrm{M})$ & $\mathrm{FSH}(\mathrm{F})$ \\
\hline Cell differentiation & fgfr4 & fibroblast growth factor receptor 4 & LH(M) & $\mathrm{LH}(\mathrm{F})$ \\
\hline \multirow{3}{*}{ Transcription factore } & $z a x$ & homeobox protein zampogna & FSH(M) & $\begin{array}{l}\text { LH(M\&F) } \\
\text { FSH(F) }\end{array}$ \\
\hline & hnf $4 a$ & hepatocyte nuclear factor 4-alpha isoform X1 & $\mathrm{LH}(\mathrm{F})$ & $\begin{array}{c}\mathrm{FSH}(\mathrm{F}) \\
\mathrm{LH} \& \mathrm{FSH}(\mathrm{M})\end{array}$ \\
\hline & esrrb & $\begin{array}{l}\text { LOW QUALITY PROTEIN: steroid hormone } \\
\text { receptor ERR2 }\end{array}$ & $\mathrm{FSH}(\mathrm{F})$ & $\begin{array}{c}\text { LH }(\mathrm{F}) \\
\text { LH\&FSH(M) }\end{array}$ \\
\hline $\begin{array}{l}\text { Chemokine } \\
\text { receptore }\end{array}$ & $x c r 1$ & chemokine $\mathrm{XC}$ receptor 1-like isoform $\mathrm{X} 1$ & $\mathrm{LH}(\mathrm{F})$ & \\
\hline \multirow{3}{*}{ Other } & ucp & uncharacterized protein LOC102076330 & $\mathrm{FSH}(\mathrm{M})$ & $\begin{array}{c}\mathrm{LH}(\mathrm{M}) \\
\mathrm{LH} \& \mathrm{FSH}(\mathrm{F})\end{array}$ \\
\hline & ucp & $\begin{array}{l}\text { uncharacterized protein LOC102077685 isoform } \\
\qquad \text { X1 }\end{array}$ & LH(M\&F) & $\mathrm{FSH}(\mathrm{M})$ \\
\hline & f6i1 & fucolectin- 6 isoform $\mathrm{X} 1$ & $\mathrm{LH}(\mathrm{F})$ & \\
\hline
\end{tabular}


Additional EG that related to gonadotropin secretion are two types of major sex steroid receptors: estrogen receptor 2 (esr2) was enriched in both LH cells $\left(\log 2(\text { fold change })_{\text {male } / \text { females }}=5.86 / 4.35\right)$ and FSH $\left(\log 2(\text { fold change })_{\text {males } / \text { females }}=5.41 / 5.71\right)$ while the progesterone receptor $(\mathrm{pgr})$ was enriched only in LH cells, mainly in females $\left(\log 2(\text { fold change })_{\text {females }}=3.63\right)$. Steroid hormones produced by the gonads, $17 \alpha-20 \beta$ dihydroprogesterone (DHP) and estradiol (E2), play an important role in the regulation of reproduction by relaying gonadal growth up the HPG axis in a classic feedback loop $[1,61,62]$. The unique expression of their receptors in LH and FSH cells correlates with the accepted role of LH and FSH during the reproductive cycle. Both FSH and LH can increase estradiol secretions, which enhance vitellogenin synthesis, however LH primarily increases DHP secretion that enhances final oocyte maturation and ovulation $[1,61,63]$. Accordingly, esr2 has higher expression in both gonadotropic cells compared to $p g r$, which might indicate a more fundamental regulation of LH and FSH cells activity by estradiol, and a unique regulation of LH cells by DHP.

Metabolic balance is linked directly to reproductive status in vertebrates, where initiation of reproduction is affected by the amount of body energy reserves and its responsiveness to diverse metabolic factors [64-66]. Though different neuroendocrine mechanisms responsible for the association between energy balance and reproduction were identified in the hypothalamic center of mammals and fish [67-69], our data suggest there are metabolic factors that directly affect gonadotroph activity, especially on FSH cells. One of the top 10 EG that was related to metabolic regulation is the cholecystokinin receptor $(c c k r)$. CCK is a peptide hormone expressed in the central nervous system and the gut that controls different processes like digestion, satiety, and anxiety [70]. $c c k r$ had enormous expression in FSH cells (normalized read counts male $/$ female $=20112.98 / 8826.10$ ) suggesting a direct link between the gastrointestinal hormone CCK and FSH activity. In fish, CCK seems to act directly on the pituitary. An immunohistochemical study showed that CCK neurons from the brain innervate into the proximal pars distalis of the pituitary, and that CCK stimulates LH release in vitro in goldfish [65]. However, in mammals there is no evidence for its direct effect on gonadotroph activity.

Additional metabolic hormones enriched mainly in LH cells, but also in FSH cells, is apelin $(a p l n)$, a novel bioactive peptide that plays pivotal roles in various physiological functions like energy metabolism, food intake, angiogenesis, and neuroendocrine functions [71,72]. In mammals, it is known to suppress LH secretion [73,74] while in fish, apln was mainly characterized with regard to feeding regulation [75-77] and development [78]. Due to its relatively high fold change expression in LH cells (log2(fold change) $=5.05$ ), it might also exhibit paracrine and endocrine regulation on the HPG axis in fish, mainly on LH activity.

Additional genes that relate to different functions like signal transduction, cell morphology, protein trafficking, transcription factors, and more (Table 1) had been identified in the top 10 EGs. While the exact roll of most of these genes in the gonadotrophs is unknown, the unique expression of known regulatory genes like esr2, pgr, cckr, and apln in each cell type reveal differences in the steroid feedback regulation, metabolic regulation, and cell signaling in each cell type.

\subsection{The Unique GPCR Signatures of Each Gonadotropic Cell}

The release of LH and FSH is regulated through neuropeptides that are secreted from the brain and relay their activity through specific receptors that frequently belong to the GPCR family [1]. Identification of different endocrine regulators of LH or FSH secretion has been a challenging task often attempted by identifying specific changes in a mixed cell population or in a bi-hormonal population of cells. Though $\mathrm{GnRH}$ is the main neuropeptide regulating both GtHs' secretion in vertebrates [1], identifying additional GPCRs of novel peptides that are differentially expressed in each $\mathrm{GtH}$ cell can reveal the unique regulation of each hormone. 
In our transcriptome analysis, we had identified 29 GPCRs in males that were enriched in each cell type specifically, and 6 that were enriched in both LH and FSH. In females, 22 and 23 genes are enriched in LH and FSH cells, respectively, while only 2 are enriched in both (see Supplementary Tables S4 and S5 for detailed GPCR list). The GPCRs were divided into 11 families according to BRITE annotation (Figure 5A,B). The different GPCRs revealed the direct regulation of important molecules like phoenixin-20 (through GPR173), which promotes oocyte maturation in zebrafish [79] and increases GnRH, LH, and FSH transcription in the pituitary of the spotted scat [80]); Dopamine (through drd2), which is known to inhibit LH secretion in fish [1,61], and additional molecules and peptides that relate to adhesion, vision, secretion, and more. The GPCR families with the highest number of genes in males and females are "peptide receptors" and "metabolic glutamate receptors", which will be addressed in the following sections (Figure 5C).

A

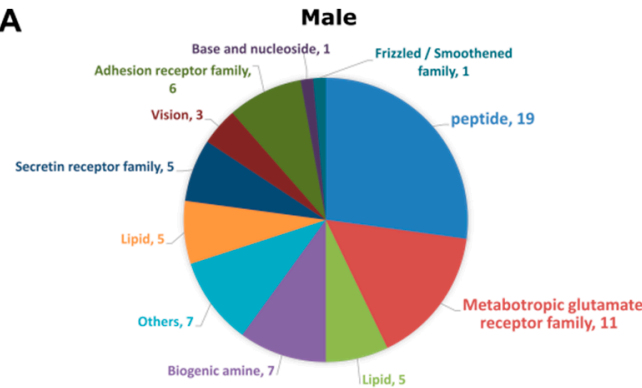

B

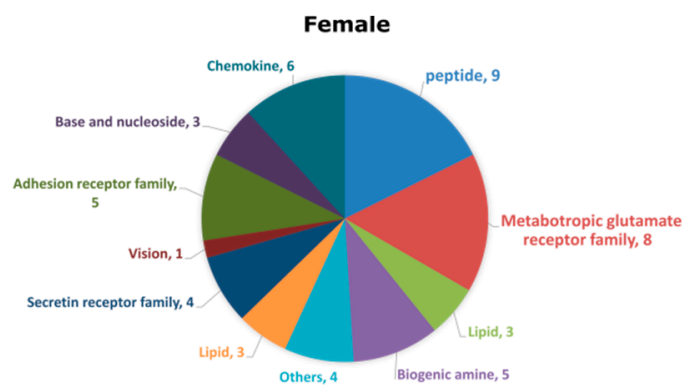

C
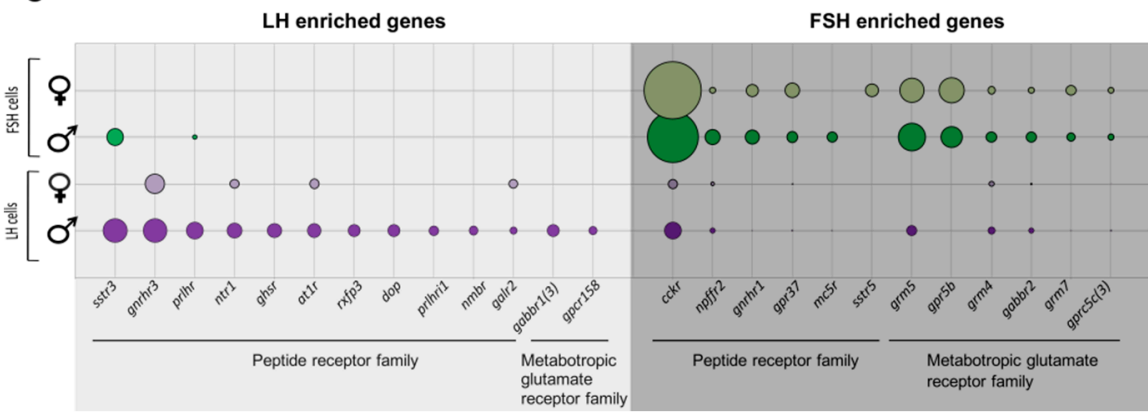

LH\&FSH enriched genes

Figure 5. Enriched GPCRs in LH and FSH cells. (A,B) Pie charts describing the number of genes in each GPCR family that are enriched in the gonadotrophs of males (A) and females (B) according to BRIT annotation. The two GPCR families with highest number of genes are the peptide receptors family and the metabotropic glutamate receptor families. Supplementary Tables S4 and S5 contain detailed information of the genes in all identified GPCR families. (C) A bubble plot revealing the $\log$ 2(fold change) expression of GPCRs from the peptide and metabotropic glutamate receptors families. Genes were divided to LH enriched, FSH enriched, and LH and FSH enriched genes according to the clustergram analysis (Figure 3B,C). Each row represents the fold change of genes in the FSH (green) or LH (magenta) cells compared to the negative, in males or females respectively. Though $\mathrm{GnRH}$ is considered the main hormone regulating gonadotropins activity, this analysis reveals a complete repertoire of hormones regulating each gonadotroph in a specific manner, and in some cases they are thought to be more significant than GnRH as their fold expression is higher, such as CCK in FSH cells and SST in LH cells. The bubble plot was prepared using Excel and visualized in Inkscape.

Not surprisingly, one of the peptide receptors with the highest fold change in LH cells is the GnRH receptor ( $g n r h r)$. In FSH cells, gnrhr is highly expressed but is only second to $c c k r$ (discussed in Section 2.5). In Nile tilapia, three different types of GnRH receptors have been identified [81,82]. In the current RNA-seq, we identified cell-specific enrichment

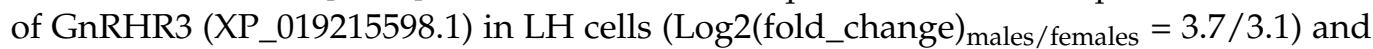
GnRHR1 (NP_001266689.1) in FSH cells (Log2(fold_chang) males/females $=2.26 / 1.99$ ). The fact that each gonadotropic cell type expresses a different GnRHR form, while both respond 
to the same GnRH peptide, might indicate a differential cell signaling processes regulating $\mathrm{LH}$ and FSH secretion in fish.

The rest of the peptide receptors enriched in LH and FSH cells relate to metabolic processes like regulation of energy balance, homeostasis, growth, and appetite. Reproduction and energy balance are two physiological processes directly linked and evolutionarily conserved [66]. As in mammals also in fish, initiation of reproduction is affected by the amount of body energy reserves and its responsiveness to diverse metabolic factors [48,64-66]. In mammals, different hormones were suggested to regulate the interplay between food intake and growth to reproduction: ghrelin, PYY3-36, kisspeptin, and leptin $[67,83,84]$, all of which regulate $\mathrm{GnRH}$ activity in the brain. In teleosts, the regulation of different metabolic factors on GtH activity was suggested to be either by regulating GnRH neurons in the hypothalamus or by stimulating gonadotrophs directly in the pituitary gland [65], however, how the different peptide differentially regulate $\mathrm{GtH}$ secretion is yet to be resolved.

One of the metabolic peptides regulating both cell types that was identified by its GPCRs expression is somatostatin, where somatostatin receptor 3 (sstr3) is enriched in males in LH cells (log2(fold change) $=3.7$ ) but also to a lower extent in FSH cells $(\log 2($ fold change $)=2.71)$ and somatostatin receptor 5 iso $3(s s t r 5)$ is expressed in FSH cells in females $(\log 2$ (fold change $)=2.08$ ). In tilapia, as in other fish species, somatostatin (SST) is mainly known to downregulate GH secretion [85], but also it inhibits secretion of other pituitary hormones like prolactin, ACTH, and LH [86]. In other vertebrates, SST was mainly found to regulate the pulsatile secretion of LH; in the ewe, ICV infusion of SST abolished the pulsatile secretion of LH and dramatically decreased its plasma levels [87]. In a lactating rat, SST signaling was shown to mediate the suckling-induced suppression of pulsatile LH secretion, while central injection of SST antagonist caused a significant increase in pulsatile LH release [88]. Expression of different SST receptor types on LH and FSH cells demonstrates sexual dimorphism in the regulation of SST on GtHs.

An additional three GPCRs of metabolic peptide are common to both cell types and are expressed in males; the adropin receptor (gpr19, $\log 2$ (fold change) LH $\left./ \mathrm{FSH}_{1}=1.46 / 1.82\right)$, the neuropeptide $\mathrm{W} /$ neuropeptide $\mathrm{B}$ receptor (npbwr1, $\log 2(\text { fold change })_{\mathrm{LH} / \mathrm{FSH}}=2.14 / 2.33$ ), and the relaxin-3 receptor $\left.(r x f p 3, \log 2 \text { (fold change })_{\mathrm{LH} / \mathrm{FSH}}=1.55 / 1.46\right)$. In mammals, these GPCRs are activated by peptides that relate to diverse physiological functions [89-92]. In fish, adropin and neuropeptide W/neuropeptide B (NPWB) were associated with GH regulation [93]; however, their regulation in the HPG axis is unknown. However, relaxin3 was previously found to increase LH secretion in the rat [94], and increased $\operatorname{lh} \beta$ and $f \operatorname{sh} \beta$ transcription in immortalized mouse gonadotrophs (L $\beta$ T2 cells) [95]. In fish, relaxin-3, together with its receptor ( $r x f p 3)$, are expressed in the gonad and are suspected to be involved with estradiol-dependent events in follicular development [96].

The expression of the above-mentioned GPCRs suggests that both cell types are regulated by the same hormones and the differential secretion of each hormone is either by different internal signal processes unique to each cell, or by additional hormones uniquely regulating each cell type. The following sections describe metabolic hormones supposed to differentially regulate each cell type according to their cell-specific GPCR expression in our transcriptome (Figure 5C).

\subsubsection{Hormones Directly Regulating LH Cells}

In our transcriptome, we had identified GPCRs related to energy balance expressed exclusively in LH cells. Though some of the hormones are known to affect LH secretion in mammals or fish, we reveal here that in a mono-hormonal gonadotroph system their effect can be directed only to LH cells.

Ghrelin receptor, also known as growth hormone secretagogue receptor (GHSR), was enriched in LH cells in males (log2(fold_change) $=2.3$ ). In mammals, ghrelin was first found to increase food intake, but also demonstrated a diversity of biological actions, including promoting secretion of GH and inhibiting LH secretion [97]. Ghrelin is also known to be involved in appetite and GH secretion in fish but, as opposed to mammals, 
it acts as a stimulatory factor in reproduction [65]. In goldfish and carp, it was shown to increase LH transcription and secretion in vivo and in vitro using dispersed pituitary cell cultures [98-100].

Two different isoforms of the prolactin-releasing peptide receptor (prlhr and prlhri1; GPR10) are enriched in LH cells in males ( $\log 2$ (fold change) $=2.6 / 1.6$, prlhr and prlhri1 respectively). Prolactin-releasing peptide (PrRP) is known to regulate PRL secretion in the context of osmolarity adaptation in tilapia [101,102]. The involvement of PrRP along the HPG axis in fish is vague. In mammals, PrRP expression seems to be affected by gonadal estrogen secretion, where its expression increases in female rats in proestrus and after administration of estrogen or progesterone in ovariectomized rats [103], associating its activity to the reproductive cycle.

An additional homeostasis-related receptor is the angiotensin II receptor type1 (at1r) which is enriched in LH cells in females ( $\log 2($ fold change) $=1.6)$ and males (Log2(fold change) $=2.2$ ). In mammals, angiotensin II is a part of the renin-angiotensin system known for regulating electrolytes and blood pressure, but has also been shown to regulate prolactin, ACTH, and LH secretion [104]. In fish, angiotensin II is mainly involved in blood pressure and water homeostasis [105] and the only evidence for its role in reproduction is due to the expression of angiotensin-converting-enzyme 2 (ace2) in the gonad of rainbow trout [106], supporting a role of at1r expression in LH cell secretion.

The Neurotensin receptor (ntr1) is enriched in LH cells in females and males $\left(\log 2(\text { fold change })_{\text {males } / \text { females }}=2.3 / 1.52\right)$. Many studies have revealed versatile physiological and behavioral roles for Neurotensin, like body temperature regulation, feeding, analgesia, ethanol sensitivity, psychosis, substance use, and pain $[107,108]$. Though in fish there is no direct evidence for its effect on reproduction, in mammals, Neurotensin inhibits LH secretion indirectly via GnRH neurons [107] and directly on hemi-pituitaries incubated in vitro [109]. Due to the unique expression of $n t r 1$ in LH cells, it is probably also regulating its secretion in fish.

The Delta opioid receptor (dop) is enriched in LH cells in males (Log2(fold change) $=1.9)$. Opioids regulate pain, behavior, and appetite, and are considered to have negative effects on LH secretion in mammals $[110,111]$. In fish on the other hand, opioid action on LH secretion can be contradicting and was suspected to affect the hypothalamic control of LH secretion. In carp, opioids inhibit LH secretion in females and stimulate LH secretion in males through the GnRH and dopaminergic systems [112,113]. In a Mozambican tilapia (Oreochromis mossambicus), the endogenous opioid peptide leu-enkephalin had stimulatory and inhibitory effects on the ovary suspected to be mediated through GnRH [114]. The opioid receptor expression on LH cells in our transcriptome analysis implies its regulation is directly on LH cells.

Galanin receptor 2 (galr2) is enriched in LH cells in females and males $\left.(\text { Log2 (fold change })_{\text {females } / \text { males }}=1.49 / 1.2\right)$. Galanin is an important neuropeptide associated with regulation of feeding and reproductive behavior. In some fish species, projections of galanin expressing neurons were found in the proximal pars distalis [65], potentially increasing the secretion of prolactin, GH, and LH [115]. Spexin (SPX), an additional neuropeptide that was found to be a functional agonist of galr $2[16,116]$, inhibited LH- and to a lesser extent FSH- secretion in vivo and directly inhibited the action potential in $\mathrm{LH}$ cells [16], confirming galr 2 expression in LH cells.

Neuromedin receptor B $(n m b r)$ is enriched in LH cells in males (Log2(fold change) $=1.4)$. Neuromedin B (NMB) is a highly conserved bombesin-related peptide that affects smooth muscle contraction, satiety, thermoregulation, stress, fear, and other behavioral responses [117]. In fish, there is no evidence for its activity in the literature. In mammals, little is known regarding its activity. In the HPG axis, a recent study cloning NMB and its receptor in pigs reveals differential expression of NMB and NMBR during development and reproductive stages in the pituitary [118], connecting its activity to the HPG axis.

Our results are the first direct evidence for the local regulation of these important metabolic and homeostatic hormones on LH cells, Though most of the hormones were 
suspected to regulate LH activity via the hypothalamic center, their GPCRs expression in LH cells reveals how LH is directly and specifically regulated by these hormones.

\subsubsection{Hormones Directly Regulating FSH Cells}

To our surprise, the main GPCRs identified in our transcriptome analysis that are enriched in FSH cells relate mainly to appetite, homeostasis, and especially glutamatergic and GABAergic systems. One of the novel findings is the potential direct regulation of FSH by the gastrointestinal peptide, CCK, since its GPCR ( $c c k r)$ is the highest enriched in FSH cells $(\log 2 \text { (fold change) })_{\text {male }} /$ female $\left.=7.92 / 8.85\right)$, we suspect that CCK might be a leading candidate for FSH regulation in fish. In mammals, different studies have revealed the existence of GnRH-independent FSH pulses [119-121], implying an additional unknown FSH releasing factor [122]. In fish, the direct regulation of GnRH on FSH transcription/secretion is even less characterized. In some species like Nile tilapia, Atlantic cod, and salmon, it was shown to directly stimulate FSH cell activity $[9,58,123]$ but to a lesser extent than LH, implying there is an additional candidate regulating FSH activity.

An additional GPCR that was enriched in FSH cells in females (Log2(fold change) $=1.05$ ) and males (Log2(fold change $)=2.42)$ was the Neuropeptide FF receptor $2(n p f f r 2)$. Belonging to the RFamide receptors family, this receptor was recently described as a regulator of diet-induced thermogenesis and bone homoeostasis [124]. RFamide neuropeptides play different roles related to pain response, energy homeostasis, anti-inflammation, and more [125]. RFamide neuropeptides were shown to inhibit GnRH activity [126] and also directly affect gonadotrophs by inducing LH and FSH secretion from fish pituitary cell culture [9], supporting npffr2 expression in FSH cells.

Two of the GPCRs that are specifically enriched in FSH cells are less known to be involved either in FSH regulation or in the HPG axis in general: the melanocortin receptor 5 ( $m c 5 r$ ) and prosaposin receptor (gpcr37). MC5R is specifically enriched in FSH cells in males $(\log 2$ (fold change) $=1.67)$ and is considered part of the melanocortin system. Though different melanocortins are known to regulate the interplay of hypothalamic regulation on food intake and the hormones involved in the HPG axis in mammals [127], the specific roll of MC5R was primarily associated with exocrine gland physiology $[128,129]$ and pheromoneinduced aggression in the rat [130]. In fish, MC5R activity is even less studied and proposed to be related to steroidogenesis and lipolysis [131]. Though the effects mediated by MC5R on FSH activity are unknown, its expression might imply for an exclusive activity on FSH in fish. Gpcr37 is highly enriched in FSH cells in males (log2(fold change) $=1.81$ ) and females $(\log 2$ (fold change $)=2.41)$. Its ligand, prosaposin (also known as SGP-1), is an intriguing multifunctional protein that plays roles both intracellularly as a regulator of lysosomal enzyme function, and extracellularly as a secreted factor [132]. The role of this receptor along the HPG axis is still unknown in vertebrates.

The metabotropic glutamate receptor family is divided into two main types of receptors: glutamate receptors and GABA receptors. While only two GPCRs from this family are enriched specifically in LH cell, seven receptors are enriched specifically in FSH cells, suggesting that FSH cells are more susceptible to the direct regulation of GABA and glutamate activity. Glutamate and GABA are both known for their activity in the central nervous system as excitatory and inhibitory neurotransmitters, respectively [133]. In mammals and fish, both neurotransmitters are proposed to increase FSH activity $[7,134]$.

GABA type B receptor subunits (gabbr1 and gabbr2) are differentially enriched in LH and FSH cells; the type1 iso3 is enriched uniquely in LH cells in males (log2(fold change) $=1.9$ ) and the type1 iso1 is enriched in both cell types $\left(\mathrm{FSH}_{\log 2 \text { (fold change)males } / \text { females }}=2.06 / 1.3\right.$, $\mathrm{LH}_{\log 2 \text { (fold change)males/females }}=1.73 / 0.84$ ), while the type 2 subunits are enriched in FSH cells $\left(\log 2(\text { fold change })_{\text {males } / \text { females }}=1.66 / 1.06\right)$. Since only heterodimeric GABAB receptors, containing both subunit types, are functional [135], the higher expression of both subunits in FSH cells support our hypothesis that GABA is mainly regulating FSH. In addition, three types of glutamate metabotropic receptors were uniquely enriched in FSH cells; grm5 ( $\left.\log 2(\text { fold change) })_{\text {males } / \text { females }}=4.3 / 3.83\right)$, 
grm4 $\left(\log 2(\text { fold change })_{\text {males } / \text { females }}=1.74 / 1.29\right)$, and $g r m 7(\log 2($ fold change $)$ males $/$ females $=1.43$ 11.68), supporting the direct regulation of glutamate on FSH cell activity.

The GPCR genes enriched in FSH cells suggest different candidates of hormones directly regulating FSH. Whereas the high expression of $c c k r$ in FSH cells uncovers for the first time the importance of CCK in FSH regulation, in addition the vast repertoire of GABAergic and glutamatergic receptors reveals the significance of the GABA/glutamate system in specifically regulating FSH cells. How each of these hormones affects FSH activity, and the specific relationship between them, is yet to be resolved.

\subsection{Enriched Genes Conserved between Mammalian and Fish Gonadotrophs}

Determination of the different genomic, cellular, and endocrine factors that regulate specifically LH and FSH secretion in mammals is challenging because both hormones are secreted from the same cell. Since the mono-hormonal gonadotroph system had likely evolved from a bi-hormonal system, we suspect that conserved genes that are unique to a specific cell type in the mono-hormonal system will regulate the same hormone in the bi-hormonal system. Therefore, we compared the fish transcriptome analysis to that of the rat gonadotroph [26]. The list of genes described in this section relates to key functions that regulate gonadotrophic cell activity. Since the single cell method used for the rat adenohypophysis transcriptome analysis is essentially different from the transcriptome used in the current study, we cannot speculate regarding the non-detected genes in this context, therefore, we only compared identified genes (Figure 6). Moreover, here we highlight only the genes that are uniquely enriched in the gonadotrophs of both tilapia and rat, therefore genes that are common to other cell types are not discussed. Out of the 95 dominant genes in the rat gonadotrophs only 15 were shared with tilapia FSH cells (Figure 6A) and 7 with LH cells (Figure 6B). Out of the 95 genes, only one orthologue was expressed in both gonadotropic cell types (Figure 6C): the gap-junction delta 2 protein (gjd2b), which encodes connexin 36 (Cx36). Gap junctions are suggested to be important to ensure efficient, synchronous secretion of gonadotropins in mice [136] and in LH cells in Nile tilapia [17]. Whereas Cx36 has been identified to specifically mediate coupling between mammalian gonadotrophs [136], this is the first evidence for its expression in fish gonadotrophs. Cx36 expression in rat and fish gonadotrophs suggest the functional important of the coupling mechanisms in both mono- and bi-hormonal gonadotrophs. Moreover, this conserved evolutionary gene may serve as a candidate for a marker of gonadotrophs in the vertebrate pituitary.

Electric excitability of gonadotropic cells is directly related to their activity and secretion $[53,58,59]$. Therefore, the different ion channels expressed in each cell might suggest that there is a different excitability pattern for LH and FSH which finally affect their release patterns. Few potassium channels are conserved between rat and tilapia. In tilapia FSH cells, specific potassium voltage gated channels are enriched $(k c n h 6 a$, NRmales $/$ females $=1509.5 / 951.5$, and two isoforms of $k c n a 4$, average $N R=295.9)$ while in tilapia LH cells the $\beta$ subunit of a calcium activated potassium channel $(k c n m b 2, \mathrm{NR}=276.3)$ is enriched in males. $\mathrm{KCNM}$ channels were specifically shown to regulate $\mathrm{Ca} 2+$ oscillation and specifically affect LH secretion in rat gonadotrophs [54]. KCNM channels are composed of a pore-forming $\alpha$ subunit and additional auxiliary $\beta$ and $\gamma$ subunits. The auxiliary subunits can be differentially expressed in different cells [137]. The $\beta 4$ subunit that is only enriched in male tilapia LH cells is also conserved in male rat gonadotrophs [26], and is known to slow down the activation and deactivation kinetics of the KCNM channel by decreasing $\mathrm{Ca} 2+$ sensitivity at low $\mathrm{Ca} 2+$ concentrations and increasing $\mathrm{Ca} 2+$ sensitivity at high $\mathrm{Ca} 2+$ concentrations $[137,138]$, therefore contributing to the oscillatory properties of LH cells in mammals, that were suggested also in fish [55]. This unique modulation of the KCNM channel can be a conserved function that reflects different excitatory properties between LH and FSH cells in fish and mammals. 
A

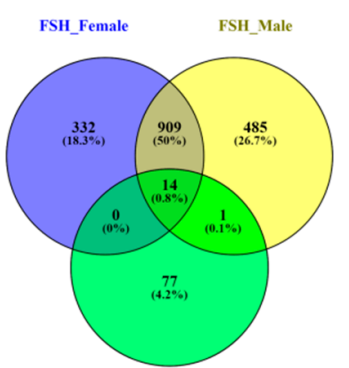

Rat_G

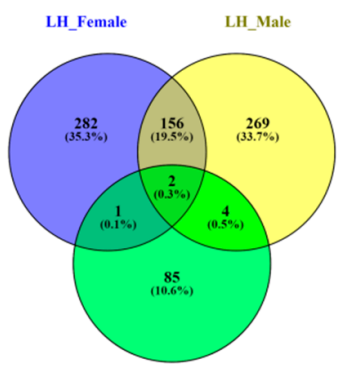

Rat_G

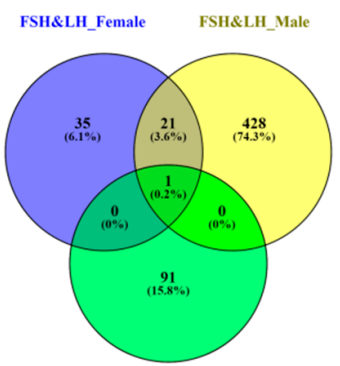

Rat_G

B

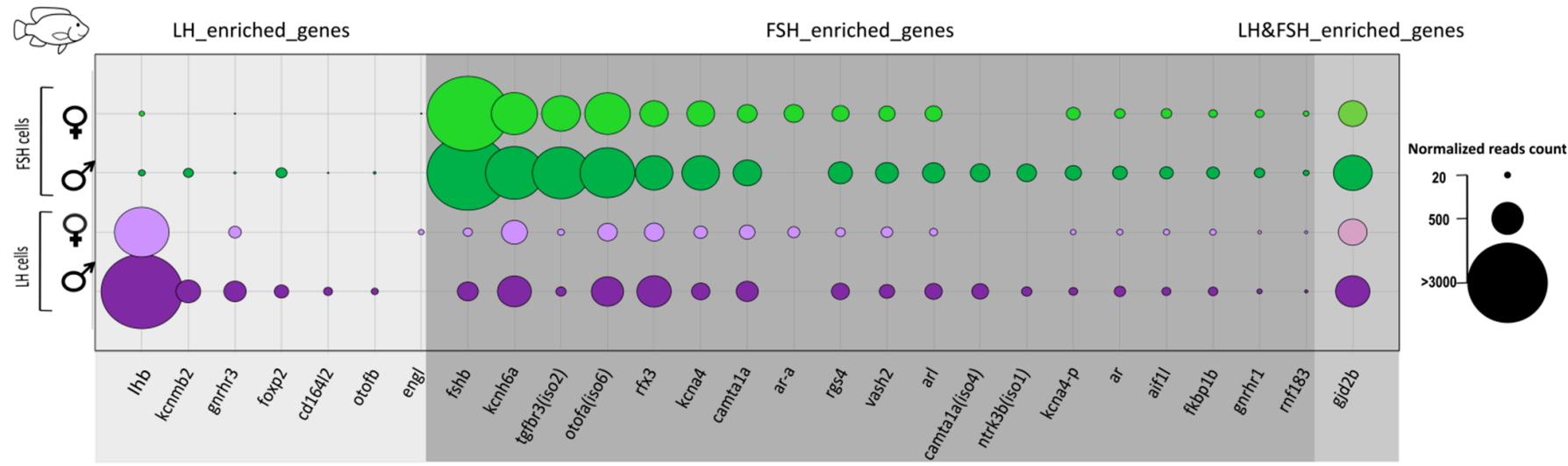

C

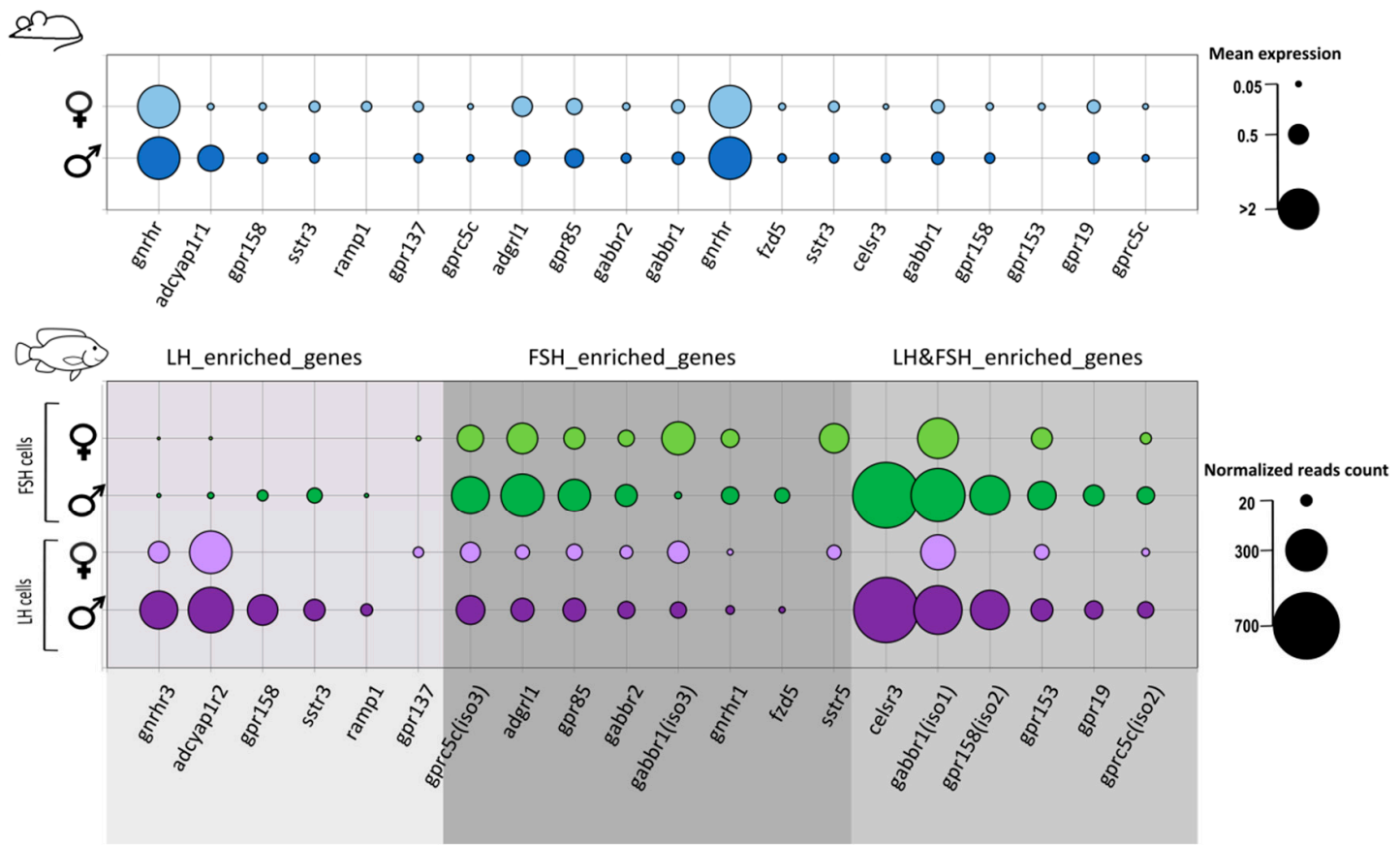

Figure 6. Shared genes between Nile tilapia gonadotrophs and rat gonadotrophs. (A)Venn diagrams describing the number of shared genes between the dominant genes expressed in rat gonadotrophs (according to Fletcher et al.) [26] and enriched genes of tilapia specific gonadotropic cell types in each sex, the classification of enriched genes in each cell type are according to the clustergram analysis (Figure 3B,C). To ensure gene ID are compatible between the different organisms, the rat IDs were converted to the zebrafish IDs using g:profiler orthology search tool and the tilapia ID to zebrafish ID as described in 
the methods (Section 3.7). From the 95 dominant genes identified in the rat gonadotrophs only 23 genes were common to tilapia, most of which are in FSH cells. Supplementary Table S6 lists the common genes and their expression values in each cell type. Venn diagram was created using Venny_2.1 (https://bioinfogp.cnb.csic.es/tools/venny/) (accessed on 24 September 2019). (B) A bubble plot describing the expression in tilapia of the shared genes between the rat gonadotrophs (males and females) and tilapia gonadotrophs according to the Venn diagrams in A. The size of the bubble reflects the normalized read (NR) count in each cell type in each sex and the genes are arranged according to their classified cluster (LH enriched, FSH enriched, of LH and FSH enriched). In some cases, the same gene in the rat contains different isoforms which are unique to each cell type in tilapia like gnrhr or sstr and in some cases different genes are classified in specific cell type like the ar gene in FSH cells and the kcnmb2 gene in LH cells. This ability to classify the common genes to each cell type can give us a clue regarding the regulation of each gonadotropic hormone also in mammals. The only gene common to both cell type is the $g j d 2 b$ gene revealing the importance of this unique gap junction in vertebrate gonadotrophs. (C) A bubble plot describing the expression of GPCR genes that are common to mammals (according to Fletcher et al.) [26]) and fish. The genes are arranged according to their classified cluster (LH enriched, FSH enriched, LH and FSH enriched). Bubble size represents the mean expression or the normalized reads of rat and tilapia gonadotrophs respectively in males and females. Though in the rat GnRH is the highest expressed GPCR in tilapia, other GPCRs have higher expression values in each cell type, especially in FSH cells, suggesting for different candidates regulating FSH activity. Supplementary Table S7 lists the common GPCRs and their expression values in each cell type in rat and tilapia. Bubble plots were prepared using Excel and visualized in Inkscape.

Mouse gonadotrophs express the androgen receptor (ar), which plays an important role in the feedback regulation from the gonads [139]. Gonadotroph-specific knockout of mouse ar disrupted gonadal development and fertility. In the fish pituitary, the expression of $a r$ is correlated to different developmental stage of the gonad and is highly expressed in reproducing Nile tilapia [140-142]. Three different ar paralogs (ard, ar like, and ar) are enriched in FSH cells (average NR = 132.9), suggesting their activity is mainly related to FSH secretion during vitellogenesis. Additional transcription factors and signal transduction regulators are conserved between rat and tilapia like; rgs4, foxp2, otofb, and more, however, how they affect each hormone regulation is unknown.

To identify endocrine hormones regulating the activity of FSH and LH cells, we looked at the conserved GPCRs between tilapia and rat gonadotrophs (Figure 6E), and as much as 20 of the 70 identified GPCR genes enriched in tilapia gonadotrophs were shared with the rat gonadotroph transcriptome analysis. The genes were divided to LH and FSH cell groups according to their expression in the tilapia transcriptome analysis. Other than the conserved regulation of GnRH on both gonadotrophs activity, additional receptors from the peptide family were identified like somatostatin receptor and adropin receptors, emphasizing their importance in LH and FSH regulation. Moreover, the expression of GPCR genes that relate to the metabotropic glutamate receptors family like gabbr1 and gabbr2 in the rat gonadotrophs reveals conserved GABAergic regulation on those cells, probably related to FSH secretion/transcription due to their high expression in FSH cells in tilapia. The fact that many of the GPCRs already discussed in Section 2.6 are conserved in rat gonadotrophs highlight their importance in differentially regulating gonadotroph activity in mammals.

In LH cells, pituitary adenylate cyclase- activating polypeptide type 1 receptor isoform 1 (adcyap 1r1) is enriched in males ( $\mathrm{NR}=324.6)$ and females $(\mathrm{NR}=282.7)$. Classified in the secretion receptor family according to BRITE analysis (see Supplementary Tables S4 and S5), this receptor and its ligand (PACAP) are known to play an important role in regulating the HPG axis in both mammals and fish [47,143-145]. In mammals, PACAP can either inhibit or elicit gonadotropin secretion depending on the sex, the reproductive stage, and application method [143]. In fish, PACAP increased LH secretion in the gonadotrophs of the goldfish [144], while in previous studies performed on cell culture of tilapia pituitaries, it increased both LH and FSH subunit synthesis [47]; unfortunately how it affects the secretion of FSH in fish is yet unknown. However, the specific expression of adcyap1r1 in tilapia LH cells strengthens its importance for LH activity. 
Latrophilin1 (adgrl1) is a member of the adhesion receptor family and is found to be conserved in rat gonadotrophs and tilapia FSH cells. The activity of adgrl1 has been extensively studied as a component of black widow spider venom and was found to elicit spontaneous exocytosis of neurotransmitters from neurons and peptide hormones of endocrine cells [146]. However, this is the first evidence for its expression in FSH cells and the pituitary of fish in general. Since its expression in LH cells is relatively low, it might be a candidate for the regulation of the different secretion patterns of LH and FSH from gonadotrophs in vertebrates.

When looking at the endocrine control of gonadotropin secretion from an evolutionary perspective, few key genes which are highly conserved between very distant species had been highlighted. GnRH is considered the main neuropeptide regulating LH and FSH secretion, and even though GnRHR is the highest expressed GPCR in rat gonadotrophs, the two different isoforms of tilapia GnRHRs are not the highest GPCRs expressed in tilapia gonadotrophs. Interestingly, highly expressed GPCRs that were identified in fish transcriptome, and have higher NR counts than the GnRH receptors in fish, were not detected in the rat transcriptome, like $c c k r, n m b r, n t r 1$, and $d r d 4$. Though speculating on genes that are missing from different transcriptome analyses is problematic, the fact that these genes are highly expressed in fish, and are missing in rat, might suggest a unique adaptation for LH and FSH cells in fish that might also relate to the unique adaptation of mono-hormonal system.

\section{Materials and Methods}

\subsection{Fish Care and Maintenance}

Nile tilapia (Oreochromis niloticus, Lake Manzala strain) were kept and bred in a recirculating water system at $26-28^{\circ} \mathrm{C}$ and fed twice daily with commercial pellets $(47 \%$ protein, $6 \%$ fat, Raanan Shivuk, Israel). The double-labeled fish used for this study were grown together in a single 500-L tank. In each experiment, the fish were sampled randomly from the tank. Fish sex, weight, and gonado-somatic index (gonadal mass as a proportion of the total body weight; GSI) are detailed for every experiment; all the fish used in this study were sexually mature while their GSI ranged between $0.001-5.7 \%$ for females and $0.007-1.02 \%$ for males (Supplementary Figure S1). Double-labeled transgenic fish expressing GFP and RFP in GtH cells were the offspring of single-labeled parents; FSH:GFP that were previously described $[17,18]$ and LH:RFP that were created as previously described [45]. Using the LR Three-way Multisite Gateway reaction (Invitrogen, Carlsbad, CA, USA) the resulting construct drove tagRFP expression in LH cells and tagRFP expression in the heart. After breeding of the single-labeled fish, the embryos were screened for red and green signals in the heart, only embryos expressing both signals were considered double-labeled fish.

All experiments were conducted in accordance with the Animal Care and Use Guidelines of the Hebrew University and were approved by the National Research Council for Care and Use of Laboratory Animals.

\subsection{Confocal Imaging}

Pituitaries of adult double-labeled Nile tilapia (FSH:GFP\&LH:RFP) were fixed in $4 \%$ PFA for $2 \mathrm{~h}$ at room temperature and then cryoprotected by immersion in PBS containing $20 \%(w / v)$ sucrose and $30 \%$ OCT $(w / v)$ overnight at $4{ }^{\circ} \mathrm{C}$. Tissue was frozen in OCT blocks and sectioned in a cryostat at a thickness of $12 \mu \mathrm{m}$. The slides were stained with DAPI and mounted in anti-fade solution, pituitaries were imaged for RFP- and GFP-labeled cells using confocal fluorescent microscope (Leica microsystems), and images were produced using an $\times 20$ and $\times 60$ objectives and processed using Fiji program [147].

\subsection{Isolation of LH and FSH Cells from Double Labeled Pituitaries}

For the isolation of LH and FSH cells, pituitaries from 20 double-labeled mature males or 20 mature females of Oniloticus were harvested and validated using fluorescent microscopy for GFP- and RFP-labeled cells. Positive pituitaries expressing RFP and GFP 
from each sex were validated in a fluorescent microscope and pooled together into a modified HBS (HEPES Buffered Saline; $145 \mathrm{mM} \mathrm{NaCl}, 5.4 \mathrm{mM} \mathrm{KCl}, 1.8 \mathrm{nM} \mathrm{CaCl} 2,1 \mathrm{mM}$ $\mathrm{MgCl} 2,20 \mathrm{mM}$ D-Glucose, $20 \mathrm{mM}$ HEPES). Next, the pituitaries were digested by trypsin into a single cell suspension according to $[9,148]$. The cell suspension was filtered through a $40 \mu \mathrm{m}$ sieve and suspended in PBS containing 30\% Accumax (SCR006 Accumax cell detachment solution, Mercury-ltd, Rosh-Ha'ayin, Israel.). The procedure was repeated four times for each sex, generating four biological replicates for each sex, totaling 76 female fish (body weight 78.82 $\pm 2.61 \mathrm{~g}$; GSI $1.9 \pm 0.2 \%$ ) and 77 male fish (body weight $143.16 \pm 7.05 \mathrm{~g}$; GSI $0.22 \pm 0.04 \%$ ) were used (Supplementary Figure S1). The cell suspensions were sorted in a FACSAriaIII sorter using a $488 \mathrm{~nm}$ and $561 \mathrm{~nm}$ lasers to excite the GFP- and RFP-labeled cells, respectively. To determine the correct parameters of gaiting for the positively-labeled cell population (Supplementary Figure S2), different pituitaries served as controls: non-labeled, single-labeled of FSH:GFP, and single-labeled of LH:RFP. Cell viability was also determined using the fluorescent exclusion dye, propidium iodide (Merck KGaA, Darmstadt, Germany). Four fractions were collected: GFP-positive fraction enriched in FSH cells, RFP-positive fraction enriched in LH cells, GFP- and RFP-positive that contain both cell types probably due to doublets of LH and FSH cells, and negative cells fraction that contain non-LH and non-FSH pituitary cells. For each cell suspension, 23,000 to 60,000 cells were collected simultaneously.

\subsection{RNA-Seq Library Preparation of FACS Cells}

After sorting, cells were immediately centrifuged $(300 \times \mathrm{g}$ for $4 \mathrm{~min})$ and suspended in Trizol ${ }^{\circledR}$ Reagent (Thermo Fisher Scientific, Waltham, MA, USA) for total RNA extraction, according to the manufacturer's instruction. Total mRNA from each sample was dissolved in $20 \mu \mathrm{L}$ DEPC water with concentrations ranging from 0.9 to $4.3 \mathrm{ng} / \mu \mathrm{L}$ (Figure $2 \mathrm{C}$ ). RNA quality and quantity were verified using a 2200 TapeStation (Agilent Technologies). Total RNA samples were sent to the Interdepartmental Equipment Unit, Faculty of Medicine (The Hebrew University) for RNA-seq library preparation and sequencing. RNA libraries were prepared using the SMARTer ${ }^{\circledR}$ Stranded Total RNA-Seq Kit v2- Pico Input Mammalian (Takara Bio, Mountain View, CA, USA which is adaptable for low quality RNA samples. The libraries were subjected to next generation sequencing using Illumina ${ }^{\circledR}$ NextSeq ${ }^{\circledR} 500$ system (Illumina, Inc, San Diego, CA, USA), performing 76 bp single-end read sequencing of the 32 multiplexed samples. Each library contained at least $24 \mathrm{M}$ reads (in average $45.5 \mathrm{M}$ and $27.5 \mathrm{M}$ for males and females, respectively).

\subsection{RNA-Seq Library Processing, Mapping, and Annotation}

Raw reads (Fastq files) were inspected for quality issues with FastQC v0.11.4 (http:/ / www.bioinformatics.babraham.ac.uk/projects/fastqc/) (accessed on 1 September 2019) and trimmed for quality and adaptor removal using Trim Galore (https:/ / github. com/FelixKrueger/TrimGalore) (accessed on 1 September 2019) default settings. Single end reads were mapped to O. niloticus (assembly O_niloticus_UMD_NMBU GCA_001858045.3), using STAR v 2.201 [149]. Mapped reads were processed to remove identified contamination of ribosomal and bacterial RNA. From the uniquely mapped reads, an average of $43 \%$ and $47 \%$ were assigned to $\mathrm{O}$. niloticus known genes in males and females, respectively. Finally, the average number of reads that were assigned to a known gene in the O. niloticus genome, for each cell type (thus constituting the data on which the analysis is based), were, in the male pituitary FACS cells: LH cells; $2.3 \mathrm{M}$ reads, FSH cells; $4.2 \mathrm{M}$ reads, negative cells; $2.8 \mathrm{M}$, "before sorting" control cells; $4.5 \mathrm{M}$ reads. For the female pituitary FACS cells, they were LH cells; $1.6 \mathrm{M}$, FSH cells; $1.5 \mathrm{M}$ reads, negative cells; $1.4 \mathrm{M}$ reads and the "before sorting" cells; $3 \mathrm{M}$ reads per sample. FASTQ files and the results of DESeq analysis discussed in this study are available on the National Center for Biotechnology Information (NCBI) Gene Expression Omnibus (GEO) $[150,151]$ through accession number GSE159470. 


\subsection{Identifying Uniquely Expressed Genes in LH and FSH Cells}

Differential expression analysis was performed using DESeq2 $\mathrm{R}$ package. In the FACS sorted cells, each LH or FSH library was analyzed against the negative library. More than $3 \mathrm{~K}$ genes with normalized read counts greater than 100 were identified. In total, 10,713 and 10,134 genes were differentially expressed (FDR corrected $p<0.05$ ) between the gonadotrophs and the negative fractions in males and females, respectively. The distribution of the number of genes with the different read counts in each library is detailed in Supplementary Table S8. Volcano plots describing the differentially expressed genes $(\log 2>1, p<0.05)$ is detailed in Supplementary Figure S3.

To decide the fold change cutoff of enriched genes (EGs) for LH and FSH cells, we looked at the RNA-seq expression of common pituitary hormones in the different FACS fractions (Figure $3 \mathrm{~A}$ ). In order to increase the reliability of the results, only genes with a $\log 2$ fold change greater than one (above the red line in Figure $3 \mathrm{~A}$ ) were considered EGs in LH and FSH samples, eliminating genes with low expression that might arise from unwanted cell contamination in the sorted fractions. Therefore, EGs were selected according to the following cutoff criteria: FDR corrected p-value lower than 0.05 and absolute fold change expression higher than 2 . To create gene lists for uniquely expressed genes in LH, FSH, or both cell types, we performed a hierarchical clustering analysis using MATLAB (MATLAB_R2107a) based on the filtered EGs, using a Seuclidean distance matrix and a complete linkage method for the cluster analysis.

\subsection{Functional Analysis of Enriched Genes in FSH and LH Cells}

The well annotated zebrafish (D. rerio) gene homologs were used as a reference for further functional analyses of the EGs. For the purpose of assigning zebrafish homologs to tilapia protein sequences, they were further aligned against a database containing all zebrafish protein sequences (genome version GRCz11) using GHOSTX-An Improved Sequence Homology Search Algorithm [152]. Sequences were selected as homologues if BLAST e-value were lower than 10-5 and sequence identity was higher than $60 \%$. The zebrafish proteins with the highest blast bit-score (along with its annotations) were assigned to each one of the tilapia proteins as their representative homolog. Enrichment analysis of GO terms and KEGG pathway was performed using the g:Profiler [153], the genes were categorized according to their fold change in each cell type, and uploaded to g:Profiler using the zebrafish organism as reference. The different enriched GO annotations were later grouped using the CateGOrizer tool (https://www.animalgenome.org/tools/catego/) (accessed on 1 September 2019).

\subsection{Real-Time PCR Validations}

cDNA preparation was accomplished with 2 ng of the FACS cells mRNA using the Verso cDNA Synthesis Kit (Thermo Fisher Scientific, Waltham, MA, USA) according to the manufacturer's instruction. Real-time PCR validations were performed as described previously [154]. cDNA $(3 \mu \mathrm{L})$ was used as template in a $20 \mu \mathrm{L}$ final reaction volume with Platinum SYBR Green qPCR SuperMix (Invitrogen). Each set of primers were validated first for specificity and efficiency using 6 dilutions $(\times 5)$ of pituitary cDNA. To assess the mRNA expression of $\mathrm{lh} \beta, \mathrm{fsh} \beta$, and gh in each fraction, mRNA levels (the averaged of two technical replicates) were normalized against the reference gene, $\mathrm{EF} 1 \alpha$, using the comparative threshold cycle method $(-\Delta \mathrm{CT})$. Ef1 $\alpha$ was previously shown to be a suitable reference gene for gene expression in several fish species including tilapia [14,154]. Primer sequences are detailed in Supplementary Table S1.

\subsection{Comparing Tilapia and Rat Transcriptome Analysis}

Gene lists from the rat single cell transcriptome analysis were published and kindly provided by Dr. Stojilkovic (National Institutes of Health) [26]. We obtained two different lists, one for the significantly dominant genes expressed in rat gonadotrophs and a second matching our specific GPCRs list obtained by BRITE analysis [155] and are expressed in 
at least $5 \%$ of the gonadotroph identified in the single cell analysis. Tilapia gene IDs were converted to rat IDs using g:profiler orthology search tool. The common genes between rat gonadotrophs to tilapia LH and FSH cells were identified using a Venn diagram (Venny 2.1).

\section{Conclusions}

By successfully separating LH and FSH cells from the pituitaries of Nile tilapia, we had identified cell-specific and sex-specific enriched genes that may contribute to different excitatory mechanisms, different signal transduction properties, and different hormonal regulation of these cells. We identified different types of GnRH receptors that are differentially expressed in each cell type, highlighted conserved peptides and metabotropic glutamate receptors that might contribute to the differential secretion and synthesis of each of the GtHs and potentially link between reproduction and other physiological mechanisms. One novel finding in this study was the high levels of cckr expression in FSH cells, which we hypothesize to be a link between the metabolic and reproductive status of the fish. We had identified conserved orthologues by comparing our enriched genes to that of the rat gonadotroph, revealing their contribution to the differential regulation of $\mathrm{LH}$ and $\mathrm{FSH}$, and emphasizing their importance in gonadotroph activities.

Supplementary Materials: The following are available online at https:/ /www.mdpi.com/article/10 $.3390 / \mathrm{ijms} 22126478 / \mathrm{s} 1$.

Author Contributions: Conceptualization, B.L.-S. and L.H.-C.; methodology, L.H.-C. and M.G.; formal analysis, L.H.-C.; investigation, L.H.-C.; data curation, L.H.-C.; writing-original draft preparation, L.H.-C.; writing - review and editing, B.L.-S., M.G. and L.H.-C.; supervision, B.L.-S.; funding acquisition, B.L.-S. All authors have read and agreed to the published version of the manuscript.

Funding: This research was funded by the Deutsche Forschungsgemeinschaft (PF683/5-1) and by the Israel Science Foundation (ISF) no. 1540/17.

Institutional Review Board Statement: All animal experiments followed the Institutional Ethical Guidelines of the Hebrew University of Jerusalem and were approved by the Experimentation Ethics Committee of the Hebrew University (research number: AG-17-15126, Date: 30 April 2017).

Informed Consent Statement: Not applicable.

Data Availability Statement: FASTQ files and the results of DESeq analysis discussed in this study are available on the National Center for Biotechnology Information (NCBI) Gene Expression Omnibus (GEO) $[150,151]$ through accession number GSE159470.

Acknowledgments: The authors would like to thank Stanko S. Stojilkovic and Patrick Allen Fletcher for sharing their original data on specific gene expression in the rat transcriptome [26]. The authors would like to thank Krist Hausken for his review of the initial manuscript.

Conflicts of Interest: The authors declare no conflict of interest.

$\begin{array}{ll}\text { Abbreviations } & \\ \text { Gonadotropin-releasing hormone } & \text { GnRH } \\ \text { Luteinizing-hormone } & \text { LH } \\ \text { Follicle-stimulating-hormone } & \text { FSH } \\ \text { Gonadotropin hormones } & \text { GtHs } \\ \text { Hypothalamus-pituitary-gonad } & \text { HPG } \\ \text { Rostral pars distalis } & \text { RPD } \\ \text { Proximal pars distalis } & \text { PPD } \\ \text { Pars intermedia } & \text { PI } \\ \text { Pars nervosa } & \text { PN } \\ \text { LH } \beta \text { subunit } & \mathrm{lh} \beta \\ \text { FSH } \beta \text { subunit } & \mathrm{sh} \beta \\ \text { Growth hormone } & \mathrm{gh} \\ \text { Prolactin } & \mathrm{prl} \\ \text { Thyroid-stimulating hormone } & \mathrm{tsh} \beta \\ \text { Somatolactin } & \mathrm{sl}\end{array}$


Pro-opiomelanocortin

pomc

Glycoprotein $\alpha$-subunit

$\operatorname{gc} \alpha$

Normalized read

NR

Enriched genes

EG

Gene ontology

$\mathrm{GO}$

Neurokinin B

NKB

Estrogen receptor 2

esr2

Progesterone receptor

pgr

$17 \alpha$-20 $\beta$-Dihydroprogesterone

DHP

Estradiol

E2

Somatostatin receptor

sstr

Somatostatin

SST

Adropin receptor

Gpr19

Neuropeptide W/neuropeptide B

NPWB

Relaxin-3 receptor

rxfp3

Secretagogue receptor

Prolactin-releasing peptide receptor

ghsr

Prolactin-releasing peptide

prlhr, gpr10

Angiotensin II receptor type1

PrRP

Angiotensin-converting-enzyme 2

at1r

Neurotensin receptor

ace2

Delta opioid receptor

ntr1

Galanin receptor 2

dop

Spexin

galr2

Neuromedin receptor B

SPX

Neuromedin B

$\mathrm{nmbr}$

Cholecystokinin

NMB

Apelin

CCK

apln

Calmodulin regulator protein or PEP-19

pcp4

Phosphodiesterase 6H

pde6h

Calmodulin-dependent kinase II

CaMKII

G-protein coupled receptor

Neuropeptide FF receptor 2

GPCR, gpr

Melanocortin receptor 5

npffr2

mc5r

Prosaposin receptor

gpcr37

Gamma-Aminobutyric acid

GABA

GABA type B receptor subunit1

gabbr1

GABA type B receptor subunit

gabbr2

Gap-junction delta 2 protein

gjd $2 b$

Connexin 36

Cx36

Potassium voltage-gated channel, subfamily $\mathrm{H}$

eag-related member 6a

Potassium voltage-gated channel subfamily A member 4

kcnh6a

kcna4

Calcium-activated potassium channel subunit beta-2

kcnmb2

Androgen receptor

ar

$\mathrm{G}$ protein signaling

rgs

Adenylate cyclase-activating polypeptide type 1 receptor isoform 1

Latrophilin1

adcyap1r1

Dopamine receptor

adgrl1

drd

\section{References}

1. Levavi-Sivan, B.; Bogerd, J.; Mananos, E.L.; Gomez, A.; Lareyre, J.J. Perspectives on fish gonadotropins and their receptors. Gen. Comp. Endocrinol. 2010, 165, 412-437. [CrossRef]

2. Marshall, G.R.; Bint Akhtar, F.; Weinbauer, G.F.; Nieschlag, E. Gonadotrophin-releasing hormone (GnRH) overcomes GnRH antagonist-induced suppression of LH secretion in primates. J. Endocrinol. 1986, 110, 145-150. [CrossRef] 
3. Stamatiades, G.A.; Kaiser, U.B. Gonadotropin regulation by pulsatile GnRH: Signaling and gene expression. Mol. Cell Endocrinol. 2018, 463, 131-141. [CrossRef] [PubMed]

4. Dalkin, A.C.; Haisenleder, D.J.; Ortolano, G.A.; Ellis, T.R.; Marshall, J.C. The Frequency of Gonadotropin-Releasing-Hormone Stimulation Differentially Regulates Gonadotropin Subunit Messenger Ribonucleic Acid Expression. Endocrinology 1989, 125, 917-923. [CrossRef] [PubMed]

5. Thackray, V.G.; Mellon, P.L.; Coss, D. Hormones in synergy: Regulation of the pituitary gonadotropin genes. Mol. Cell Endocrinol. 2010, 314, 192-203. [CrossRef] [PubMed]

6. Denef, C. Paracrinicity: The story of 30 years of cellular pituitary crosstalk. J. Neuroendocrinol. 2008, 20, 1-70. [CrossRef]

7. Zohar, Y.; Munoz-Cueto, J.A.; Elizur, A.; Kah, O. Neuroendocrinology of reproduction in teleost fish. Gen. Comp. Endocrinol. 2010, 165, 438-455. [CrossRef]

8. Dufour, S.; Quérat, B.; Tostivint, H.; Pasqualini, C.; Vaudry, H.; Rousseau, K. Origin and Evolution of the Neuroendocrine Control of Reproduction in Vertebrates, With Special Focus on Genome and Gene Duplications. Physiol. Rev. 2020, 100, 869-943. [CrossRef]

9. Biran, J.; Golan, M.; Mizrahi, N.; Ogawa, S.; Parhar, I.S.; Levavi-Sivan, B. Direct Regulation of Gonadotropin Release by Neurokinin B in Tilapia (Oreochromis niloticus). Endocrinology 2014, 155, 4831-4842. [CrossRef]

10. Biran, J.; Ben-Dor, S.; Levavi-Sivan, B. Molecular identification and functional characterization of the kisspeptin/kisspeptin receptor system in lower vertebrates. Biol. Reprod. 2008, 79, 776-786. [CrossRef]

11. Felip, A.; Zanuy, S.; Pineda, R.; Pinilla, L.; Carrillo, M.; Tena-Sempere, M.; Gómez, A. Evidence for two distinct KiSS genes in non-placental vertebrates that encode kisspeptins with different gonadotropin-releasing activities in fish and mammals. Mol. Cell. Endocrinol. 2009, 312, 61-71. [CrossRef]

12. Hayakawa, Y.; Morita, T.; Kitamura, W.; Kanda, S.; Banba, A.; Nagaya, H.; Hotta, K.; Sohn, Y.C.; Yoshizaki, G.; Kobayashi, M. Biological activities of single-chain goldfish follicle-stimulating hormone and luteinizing hormone. Aquaculture 2008, 274, 408-415. [CrossRef]

13. Trevisan, C.M.; Montagna, E.; de Oliveira, R.; Christofolini, D.M.; Barbosa, C.P.; Crandall, K.A.; Bianco, B. Kisspeptin/GPR54 System: What Do We Know About Its Role in Human Reproduction? Cell. Physiol. Biochem. Int. J. Exp. Cell. Physiol. Biochem. Pharmacol. 2018, 49, 1259-1276. [CrossRef] [PubMed]

14. Biran, J.; Palevitch, O.; Ben-Dor, S.; Levavi Sivan, B. Neurokinin B and neurokinin B receptor: A novel system involved in controlling fish reproduction. Proc. Natl. Acad. Sci. USA 2012, 109, 10269-10274. [CrossRef] [PubMed]

15. Ogawa, S.; Sivalingam, M.; Biran, J.; Golan, M.; Anthonysamy, R.S.; Levavi-Sivan, B.; Parhar, I.S. Distribution of LPXRFa, a gonadotropin-inhibitory hormone ortholog peptide, and LPXRFa receptor in the brain and pituitary of the tilapia. J. Comp. Neurol. 2016, 524, 2753-2775. [CrossRef]

16. Cohen, Y.; Hausken, K.; Bonfil, Y.; Gutnick, M.; Levavi-Sivan, B. Spexin and a Novel Cichlid-Specific Spexin Paralog Both Inhibit FSH and LH Through a Specific Galanin Receptor (Galr2b) in Tilapia. Front. Endocrinol. 2020, 11, 71. [CrossRef] [PubMed]

17. Golan, M.; Martin, A.O.; Mollard, P.; Levavi-Sivan, B. Anatomical and functional gonadotrope networks in the teleost pituitary. Sci. Rep. 2016, 6, 23777. [CrossRef]

18. Golan, M.; Biran, J.; Levavi-Sivan, B. A novel model for development, organization and function of gonadotropes in fish pituitary. Front. Endocrinol. 2014, 5, 182. [CrossRef]

19. Kah, O. A 45-years journey within the reproductive brain of fish. Gen. Comp. Endocrinol. 2020, 288, 113370. [CrossRef]

20. Hausken, K.N.; Marquis, T.J.; Sower, S.A. Expression of two glycoprotein hormone receptors in larval, parasitic phase, and adult sea lampreys. Gen. Comp. Endocrinol. 2018, 264, 39-47. [CrossRef]

21. Kawauchi, H.; Sower, S.A. The dawn and evolution of hormones in the adenohypophysis. Gen. Comp. Endocrinol. 2006, 148, 3-14. [CrossRef] [PubMed]

22. Marquis, T.J.; Nozaki, M.; Fagerberg, W.; Sower, S.A. Comprehensive histological and immunological studies reveal a novel glycoprotein hormone and thyrostimulin expressing proto-glycotrope in the sea lamprey pituitary. Cell Tissue Res. 2017, 367, 311-338. [CrossRef] [PubMed]

23. Buechi, H.B.; Bridgham, J.T. Evolution of specificity in cartilaginous fish glycoprotein hormones and receptors. Gen. Comp. Endocrinol 2017, 246, 309-320. [CrossRef]

24. Proudman, J.A.; Vandesande, F.; Berghman, L.R. Immunohistochemical evidence that follicle-stimulating hormone and luteinizing hormone reside in separate cells in the chicken pituitary. Biol. Reprod. 1999, 60, 1324-1328. [CrossRef] [PubMed]

25. Hedges, S.B.; Marin, J.; Suleski, M.; Paymer, M.; Kumar, S. Tree of life reveals clock-like speciation and diversification. Mol. Biol. Evol. 2015, 32, 835-845. [CrossRef]

26. Fletcher, P.A.; Smiljanic, K.; Maso-Prévide, R.; Iben, J.R.; Li, T.; Rokic, M.B.; Sherman, A.; Coon, S.L.; Stojilkovic, S.S. Cell Typeand Sex-Dependent Transcriptome Profiles of Rat Anterior Pituitary Cells. Front. Endocrinol. 2019, 10, 623. [CrossRef]

27. Cheung, L.Y.M.; George, A.S.; McGee, S.R.; Daly, A.Z.; Brinkmeier, M.L.; Ellsworth, B.S.; Camper, S.A. Single-Cell RNA Sequencing Reveals Novel Markers of Male Pituitary Stem Cells and Hormone-Producing Cell Types. Endocrinology 2018, 159, 3910-3924. [CrossRef]

28. El Etreby, M.F.; El Bab, M.R.F. Localization of gonadotrophic hormones in the dog pituitary gland. Cell Tissue Res. 1977, 183, 167-175. [CrossRef] 
29. Dacheux, F. Ultrastructural localization of gonadotrophic hormones in the porcine pituitary using the immunoperoxidase technique. Cell Tissue Res. 1978, 191, 219-232. [CrossRef] [PubMed]

30. Newman, G.R.; Jasani, B.; Williams, E.D. Multiple hormone storage by cells of the human pituitary. J. Histochem. Cytochem. Off. J. Histochem. Soc. 1989, 37, 1183-1192. [CrossRef]

31. Thomas, S.G.; Clarke, I.J. The Positive Feedback Action of Estrogen Mobilizes LH-Containing, but not FSH-Containing Secretory Granules in Ovine Gonadotropes. Endocrinology 1997, 138, 1347-1350. [CrossRef]

32. Rahmanian, M.S.; Thompson, D.L., Jr.; Melrose, P.A. Immunocytochemical localization of luteinizing hormone and folliclestimulating hormone in the equine pituitary. J. Anim. Sci. 1998, 76, 839-846. [CrossRef] [PubMed]

33. Kadokawa, H.; Pandey, K.; Nahar, A.; Nakamura, U.; Rudolf, F.O. Gonadotropin-releasing hormone (GnRH) receptors of cattle aggregate on the surface of gonadotrophs and are increased by elevated GnRH concentrations. Anim. Reprod. Sci. 2014, 150, 84-95. [CrossRef] [PubMed]

34. Sower, S.A.; Decatur, W.A.; Hausken, K.N.; Marquis, T.J.; Barton, S.L.; Gargan, J.; Freamat, M.; Wilmot, M.; Hollander, L.; Hall, J.A.; et al. Emergence of an Ancestral Glycoprotein Hormone in the Pituitary of the Sea Lamprey, a Basal Vertebrate. Endocrinology 2015, 156, 3026-3037. [CrossRef] [PubMed]

35. Miki, M.; Shimotani, T.; Nozaki, M. Distribution of immunoreactivities for adenohypophysial hormones in the pituitary gland of the polypteriform fish, Polypterus endlicheri. Zool. Sci 2005, 22, 1123-1130. [CrossRef]

36. Hollander-Cohen, L.; Golan, M.; Aizen, J.; Shpilman, M.; Levavi-Sivan, B. Characterization of carp gonadotropins: Structure, annual profile, and carp and zebrafish pituitary topographic organization. Gen. Comp. Endocrinol. 2018, 264, 28-38. [CrossRef]

37. Nozaki, M.; Naito, N.; Swanson, P.; Dickhoff, W.W.; Nakai, Y.; Suzuki, K.; Kawauchi, H. Salmonid pituitary gonadotrophs. II. Ontogeny of GTH I and GTH II cells in the rainbow trout (Salmo gairdneri irideus). Gen. Comp. Endocrinol. 1990, 77, 358-367. [CrossRef]

38. Yom-Din, S.; Hollander-Cohen, L.; Aizen, J.; Boehm, B.; Shpilman, M.; Golan, M.; Hurvitz, A.; Degani, G.; Levavi-Sivan, B. Gonadotropins in the Russian Sturgeon: Their Role in Steroid Secretion and the Effect of Hormonal Treatment on Their Secretion. PLoS ONE 2016, 11, e0162344. [CrossRef]

39. Mikami, S.; Miyasaka, S.; Taniguchi, K. Light and electron microscopic immunocytochemistry of the pituitary gland of the tortoise. Arch. Histol. Jpn. 1985, 48, 373-388. [CrossRef]

40. Chiba, A.; Sakai, H.; Sato, M.; Honma, R.; Murata, K.; Sugimori, F. Pituitary-gonadal axis and secondary sex characters in the spontaneously masculinized pintail, Anas acuta (Anatidae, Aves), with special regard to the gonadotrophs. Gen. Comp. Endocrinol. 2004, 137, 50-61. [CrossRef]

41. Malashetty, V.B.; Sonar, A.; Patil, S.B. Anatomy and Histophysiological Changes in Pituitary of Calotes versicolor During Breeding and Nonbreeding Seasons. Int. J. Morphol. 2009, 27, 1223-1234. [CrossRef]

42. Mizutani, F.; Iwasawa, H.; Tanaka, S. A morphometric analysis of the subcellular distribution of LH beta and FSH beta in secretory granules in the pituitary gonadotrophs of the frog (Rana japonica). Cell Tissue Res. 1994, 277, 417-426. [CrossRef] [PubMed]

43. Kanda, S. Evolution of the regulatory mechanisms for the hypothalamic-pituitary-gonadal axis in vertebrates-hypothesis from a comparative view. Gen. Comp. Endocrinol. 2019, 284, 113075. [CrossRef]

44. Chang, J.P.; Pemberton, J.G. Comparative aspects of GnRH-Stimulated signal transduction in the vertebrate pituitaryContributions from teleost model systems. Mol. Cell Endocrinol. 2018, 463, 142-167. [CrossRef] [PubMed]

45. Golan, M.; Levavi-Sivan, B. Social dominance in tilapia is associated with gonadotroph hyperplasia. Gen. Comp. Endocrinol. 2013, 192, 126-135. [CrossRef] [PubMed]

46. Soengas, J.L.; Cerdá-Reverter, J.M.; Delgado, M.J. Central regulation of food intake in fish: An evolutionary perspective. J. Mol. Endocrinol. 2018, 60, R171-R199. [CrossRef]

47. Yaron, Z.; Gur, G.; Melamed, P.; Rosenfeld, H.; Elizur, A.; Levavi-Sivan, B. Regulation of fish gonadotropins. Int. Rev. Cytol. 2003, $225,131-185$.

48. Blanco, A.M. Hypothalamic- and pituitary-derived growth and reproductive hormones and the control of energy balance in fish. Gen. Comp. Endocrinol. 2020, 287, 113322. [CrossRef] [PubMed]

49. Hu, C.K.; Southey, B.R.; Romanova, E.V.; Maruska, K.P.; Sweedler, J.V.; Fernald, R.D. Identification of prohormones and pituitary neuropeptides in the African cichlid, Astatotilapia burtoni. BMC Genom. 2016, 17, 660. [CrossRef]

50. Takahashi, A.; Mizusawa, K. Posttranslational modifications of proopiomelanocortin in vertebrates and their biological significance. Front. Endocrinol. 2013, 4, 143. [CrossRef]

51. Ocampo-Daza, D.; Larhammar, D. Evolution of the growth hormone, prolactin, prolactin 2 and somatolactin family. Gen. Comp. Endocrinol. 2018, 264, 94-112. [CrossRef] [PubMed]

52. Fukamachi, S.; Sugimoto, M.; Mitani, H.; Shima, A. Somatolactin selectively regulates proliferation and morphogenesis of neural-crest derived pigment cells in medaka. Proc. Natl. Acad. Sci. USA 2004, 101, 10661-10666. [CrossRef] [PubMed]

53. Stojilkovic, S.S.; Bjelobaba, I.; Zemkova, H. Ion Channels of Pituitary Gonadotrophs and Their Roles in Signaling and Secretion. Front. Endocrinol. 2017, 8, 126. [CrossRef] [PubMed]

54. Waring, D.W.; Turgeon, J.L. $\mathrm{Ca}^{2+}$-activated $\mathrm{K}+$ channels in gonadotropin-releasing hormone-stimulated mouse gonadotrophs. Endocrinology 2009, 150, 2264-2272. [CrossRef] [PubMed]

55. Levavi-Sivan, B.; Bloch, C.L.; Gutnick, M.J.; Fleidervish, I.A. Electrotonic coupling in the anterior pituitary of a teleost fish. Endocrinology 2005, 146, 1048-1052. [CrossRef] [PubMed] 
56. Schlegel, W.; Winiger, B.P.; Mollard, P.; Vacher, P.; Wuarin, F.; Zahnd, G.R.; Wollheim, C.B.; Dufy, B. Oscillations of cytosolic Ca ${ }^{2+}$ in pituitary cells due to action potentials. Nature 1987, 329, 719-721. [CrossRef] [PubMed]

57. Mollard, P.; Schlegel, W. Why are endocrine pituitary cells excitable? Trends Endocrinol. Metab. Tem 1996, 7, 361-365. [CrossRef]

58. Hodne, K.; Strandabo, R.A.; von Krogh, K.; Nourizadeh-Lillabadi, R.; Sand, O.; Weltzien, F.A.; Haug, T.M. Electrophysiological differences between fshb- and lhb-expressing gonadotropes in primary culture. Endocrinology 2013, 154, 3319-3330. [CrossRef]

59. Fletcher, P.A.; Sherman, A.; Stojilkovic, S.S. Common and diverse elements of ion channels and receptors underlying electrical activity in endocrine pituitary cells. Mol. Cell. Endocrinol. 2018, 463, 23-36. [CrossRef]

60. Karigo, T.; Aikawa, M.; Kondo, C.; Abe, H.; Kanda, S.; Oka, Y. Whole Brain-Pituitary In Vitro Preparation of the Transgenic Medaka (Oryzias latipes) as a Tool for Analyzing the Differential Regulatory Mechanisms of LH and FSH Release. Endocrinology 2014, 155, 536-547. [CrossRef]

61. Levavi-Sivan, B.; Biran, J.; Fireman, E. Sex steroids are involved in the regulation of gonadotropin-releasing hormone and dopamine D2 receptors in female tilapia pituitary. Biol. Reprod. 2006, 75, 642-650. [CrossRef]

62. Prizant, H.; Gleicher, N.; Sen, A. Androgen actions in the ovary: Balance is key. J. Endocrinol. 2014, 222, R141-R151. [CrossRef] [PubMed]

63. Molés, G.; Hausken, K.; Carrillo, M.; Zanuy, S.; Levavi-Sivan, B.; Gómez, A. Generation and use of recombinant gonadotropins in fish. Gen. Comp. Endocrinol. 2020, 299, 113555. [CrossRef]

64. Michalakis, K.; Mintziori, G.; Kaprara, A.; Tarlatzis, B.C.; Goulis, D.G. The complex interaction between obesity, metabolic syndrome and reproductive axis: A narrative review. Metab. Clin. Exp. 2013, 62, 457-478. [CrossRef] [PubMed]

65. Shahjahan, M.; Kitahashi, T.; Parhar, I.S. Central pathways integrating metabolism and reproduction in teleosts. Front. Endocrinol. 2014, 5, 36. [CrossRef] [PubMed]

66. Schneider, J.E. Energy balance and reproduction. Physiol. Behav. 2004, 81, 289-317. [CrossRef] [PubMed]

67. Fernandez-Fernandez, R.; Martini, A.C.; Navarro, V.M.; Castellano, J.M.; Dieguez, C.; Aguilar, E.; Pinilla, L.; Tena-Sempere, M. Novel signals for the integration of energy balance and reproduction. Mol. Cell. Endocrinol. 2006, 254-255, 127-132. [CrossRef]

68. Castellano, J.M.; Roa, J.; Luque, R.M.; Dieguez, C.; Aguilar, E.; Pinilla, L.; Tena-Sempere, M. KiSS-1/kisspeptins and the metabolic control of reproduction: Physiologic roles and putative physiopathological implications. Peptides 2009, 30, 139-145. [CrossRef]

69. Hasebe, M.; Kanda, S.; Oka, Y. Female-Specific Glucose Sensitivity of GnRH1 Neurons Leads to Sexually Dimorphic Inhibition of Reproduction in Medaka. Endocrinology 2016, 157, 4318-4329. [CrossRef]

70. Rehfeld, J.F. Cholecystokinin-From Local Gut Hormone to Ubiquitous Messenger. Front. Endocrinol. 2017, 8, 47. [CrossRef]

71. Roche, J.; Ramé, C.; Reverchon, M.; Mellouk, N.; Rak, A.; Froment, P.; Dupont, J. Apelin (APLN) regulates progesterone secretion and oocyte maturation in bovine ovarian cells. Reproduction 2017, 153, 589-603. [CrossRef]

72. Kurowska, P.; Barbe, A.; Różycka, M.; Chmielińska, J.; Dupont, J.; Rak, A. Apelin in Reproductive Physiology and Pathology of Different Species: A Critical Review. Int. J. Endocrinol. 2018, 2018, 9170480. [CrossRef] [PubMed]

73. Sandal, S.; Tekin, S.; Seker, F.B.; Beytur, A.; Vardi, N.; Colak, C.; Tapan, T.; Yildiz, S.; Yilmaz, B. The effects of intracerebroventricular infusion of apelin-13 on reproductive function in male rats. Neurosci. Lett. 2015, 602, 133-138. [CrossRef] [PubMed]

74. Taheri, S.; Murphy, K.; Cohen, M.; Sujkovic, E.; Kennedy, A.; Dhillo, W.; Dakin, C.; Sajedi, A.; Ghatei, M.; Bloom, S. The effects of centrally administered apelin-13 on food intake, water intake and pituitary hormone release in rats. Biochem. Biophys. Res. Commun. 2002, 291, 1208-1212. [CrossRef]

75. Tuziak, S.M.; Rise, M.L.; Volkoff, H. An investigation of appetite-related peptide transcript expression in Atlantic cod (Gadus morhua) brain following a Camelina sativa meal-supplemented feeding trial. Gene 2014, 550, 253-263. [CrossRef] [PubMed]

76. Volkoff, H. In vitro assessment of interactions between appetite-regulating peptides in brain of goldfish (Carassius auratus). Peptides 2014, 61, 61-68. [CrossRef]

77. Hao, J.; Liu, Q.; Zhang, X.; Wu, Y.; Zhu, J.; Qi, J.; Tang, N.; Wang, S.; Wang, H.; Chen, D.; et al. The evidence of apelin has the bidirectional effects on feeding regulation in Siberian sturgeon (Acipenser baerii). Peptides 2017, 94, 78-85. [CrossRef] [PubMed]

78. Pauli, A.; Norris, M.L.; Valen, E.; Chew, G.L.; Gagnon, J.A.; Zimmerman, S.; Mitchell, A.; Ma, J.; Dubrulle, J.; Reyon, D.; et al. Toddler: An embryonic signal that promotes cell movement via Apelin receptors. Science 2014, 343, 1248636. [CrossRef] [PubMed]

79. Rajeswari, J.J.; Unniappan, S. Phoenixin-20 Stimulates mRNAs Encoding Hypothalamo-Pituitary-Gonadal Hormones, is ProVitellogenic, and Promotes Oocyte Maturation in Zebrafish. Sci. Rep. 2020, 10, 6264. [CrossRef]

80. Wang, M.; Chen, H.-P.; Zhai, Y.; Jiang, D.-n.; Liu, J.-Y.; Tian, C.-x.; Wu, T.-1.; Zhu, C.-H.; Deng, S.-P.; Li, G.-L. Phoenixin: Expression at different ovarian development stages and effects on genes ralated to reproduction in spotted scat, Scatophagus argus. Comp. Biochem. Physiol. Part B Biochem. Mol. Biol. 2019, 228, 17-25. [CrossRef]

81. Avitan, A.; Zelinger, E.; Levavi-Sivan, B. Homologous desensitization and visualization of the tilapia GnRH type 3 receptor. Gen. Comp. Endocrinol. 2007, 153, 182-188. [CrossRef] [PubMed]

82. Parhar, I.S.; Ogawa, S.; Sakuma, Y. Three GnRH receptor types in laser-captured single cells of the cichlid pituitary display cellular and functional heterogeneity. Proc. Natl. Acad. Sci. USA. 2005, 102, 2204-2209. [CrossRef] [PubMed]

83. Cunningham, M.J.; Clifton, D.K.; Steiner, R.A. Leptin's actions on the reproductive axis: Perspectives and mechanisms. Biol. Reprod. 1999, 60, 216-222. [CrossRef] [PubMed]

84. Hill, J.W.; Elmquist, J.K.; Elias, C.F. Hypothalamic pathways linking energy balance and reproduction. Am. J. Physiol. Endocrinol. Metab. 2008, 294, E827-E832. [CrossRef] [PubMed] 
85. Melamed, P.; Eliahu, N.; Levavi-Sivan, B.; Ofir, M.; Farchi-Pisanty, O.; Rentier-Delrue, F.; Smal, J.; Yaron, Z.; Naor, Z. Hypothalamic and thyroidal regulation of growth hormone in tilapia. Gen. Comp. Endocrinol. 1995, 97, 13-30. [CrossRef]

86. Gahete, M.D.; Cordoba-Chacón, J.; Duran-Prado, M.; Malagón, M.M.; Martinez-Fuentes, A.J.; Gracia-Navarro, F.; Luque, R.M.; Castaño, J.P. Somatostatin and its receptors from fish to mammals. Ann. N. Y. Acad. Sci. 2010, 1200, 43-52. [CrossRef] [PubMed]

87. Pillon, D.; Caraty, A.; Fabre-Nys, C.; Lomet, D.; Cateau, M.; Bruneau, G. Regulation by estradiol of hypothalamic somatostatin gene expression: Possible involvement of somatostatin in the control of luteinizing hormone secretion in the ewe. Biol. Reprod. 2004, 71, 38-44. [CrossRef]

88. Sugimoto, A.; Tsuchida, H.; Ieda, N.; Ikegami, K.; Inoue, N.; Uenoyama, Y.; Tsukamura, H. Somatostatin-Somatostatin Receptor 2 Signaling Mediates LH Pulse Suppression in Lactating Rats. Endocrinology 2019, 160, 473-483. [CrossRef]

89. Jasaszwili, M.; Billert, M.; Strowski, M.Z.; Nowak, K.W.; Skrzypski, M. Adropin as A Fat-Burning Hormone with Multiple Functions-Review of a Decade of Research. Molecules 2020, 25, 549. [CrossRef]

90. Ghoshal, S.; Stevens, J.R.; Billon, C.; Girardet, C.; Sitaula, S.; Leon, A.S.; Rao, D.C.; Skinner, J.S.; Rankinen, T.; Bouchard, C.; et al. Adropin: An endocrine link between the biological clock and cholesterol homeostasis. Mol. Metab. 2018, 8, 51-64. [CrossRef]

91. Chottova-Dvorakova, M. Distribution and Function of Neuropeptides W/B Signaling System. Front. Physiol. 2018, 9, 981. [CrossRef]

92. Ganella, D.; Ma, S.; Gundlach, A. Relaxin-3/RXFP3 Signaling and Neuroendocrine Function-A Perspective on Extrinsic Hypothalamic Control. Front. Endocrinol. 2013, 4, 128. [CrossRef]

93. Peng, J.; Yang, P.; Zhang, Q.; Jiang, Q. Tilapia adropin: The localization and regulation of growth hormone gene expression in pituitary cells. Peptides 2017, 97, 1-7. [CrossRef]

94. McGowan, B.M.; Stanley, S.A.; Donovan, J.; Thompson, E.L.; Patterson, M.; Semjonous, N.M.; Gardiner, J.V.; Murphy, K.G.; Ghatei, M.A.; Bloom, S.R. Relaxin-3 stimulates the hypothalamic-pituitary-gonadal axis. Am. J. Physiol. Endocrinol. Metab. 2008, 295, E278-E286. [CrossRef]

95. Kanasaki, H.; Tumurbaatar, T.; Tumurgan, Z.; Oride, A.; Okada, H.; Kyo, S. Effect of relaxin-3 on Kiss-1, gonadotropin-releasing hormone, and gonadotropin subunit gene expression. Reprod. Med. Biol. 2019, 18, 397-404. [CrossRef] [PubMed]

96. Wilson, B.C.; Burnett, D.; Rappaport, R.; Parry, L.J.; Fletcher, E.K. Relaxin-3 and RXFP3 expression, and steroidogenic actions in the ovary of teleost fish. Comp. Biochem. Physiol. Part A Mol. Integr. Physiol. 2009, 153, 69-74. [CrossRef] [PubMed]

97. Tena-Sempere, M. Ghrelin and reproduction: Ghrelin as novel regulator of the gonadotropic axis. Vitam Horm. 2008, 77, 285-300. [CrossRef]

98. Unniappan, S.; Peter, R.E. In vitro and in vivo effects of ghrelin on luteinizing hormone and growth hormone release in goldfish Am. J. Physiol. Regul. Integr. Comp. Physiol. 2004, 286, R1093-R1101. [CrossRef] [PubMed]

99. Grey, C.L.; Chang, J.P. Ghrelin-induced growth hormone release from goldfish pituitary cells involves voltage-sensitive calcium channels. Gen. Comp. Endocrinol 2009, 160, 148-157. [CrossRef] [PubMed]

100. Sokolowska-Mikolajczyk, M.; Socha, M.; Szczerbik, P.; Epler, P. The effects of ghrelin on the in vitro spontaneous and sGnRH-A stimulated luteinizing hormone (LH) release from the pituitary cells of common carp (Cyprinus carpio L.). Comp. Biochem. Physiol. Part. A Mol. Integr. Physiol. 2009, 153, 386-390. [CrossRef]

101. Seale, A.P.; Yamaguchi, Y.; Johnstone, W.M., 3rd; Borski, R.J.; Lerner, D.T.; Grau, E.G. Endocrine regulation of prolactin cell function and modulation of osmoreception in the Mozambique tilapia. Gen. Comp. Endocrinol. 2013, 192, 191-203. [CrossRef]

102. Aruna, A.; Nagarajan, G.; Chang, C.F. The acute salinity changes activate the dual pathways of endocrine responses in the brain and pituitary of tilapia. Gen. Comp. Endocrinol. 2015, 211, 154-164. [CrossRef] [PubMed]

103. Kataoka, Y.; Iijima, N.; Yano, T.; Kakihara, K.; Hayashi, S.; Hinuma, S.; Honjo, H.; Hayashi, S.; Tanaka, M.; Ibata, Y. Gonadal regulation of PrRP mRNA expression in the nucleus tractus solitarius and ventral and lateral reticular nuclei of the rat. Brain Res. Mol. Brain Res. 2001, 87, 42-47. [CrossRef]

104. Ganong, W.F. Blood, pituitary, and brain renin-angiotensin systems and regulation of secretion of anterior pituitary gland. Front. Neuroendocrinol. 1993, 14, 233-249. [CrossRef]

105. Wong, M.K.; Takei, Y.; Woo, N.Y. Differential status of the renin-angiotensin system of silver sea bream (Sparus sarba) in different salinities. Gen. Comp. Endocrinol. 2006, 149, 81-89. [CrossRef] [PubMed]

106. Bobe, J.; Montfort, J.; Nguyen, T.; Fostier, A. Identification of new participants in the rainbow trout (Oncorhynchus mykiss) oocyte maturation and ovulation processes using cDNA microarrays. Reprod. Biol. Endocrinol. RbE 2006, 4, 39. [CrossRef] [PubMed]

107. Boules, M.; Li, Z.; Smith, K.; Fredrickson, P.; Richelson, E. Diverse roles of neurotensin agonists in the central nervous system. Front. Endocrinol. 2013, 4, 36. [CrossRef]

108. Torruella-Suárez, M.L.; McElligott, Z.A. Neurotensin in reward processes. Neuropharmacology 2020, 167, 108005. [CrossRef]

109. McCann, S.M.; Vijayan, E.; Koenig, J.; Krulich, L. The effects of neurotensin on anterior pituitary hormone secretion. Ann. N. Y. Acad. Sci. 1982, 400, 160-171. [CrossRef]

110. Dobek, E.; Górski, K.; Romanowicz, K.; Misztal, T. Different types of opioid receptors involved in the suppression of LH secretion in lactating sheep. Anim. Reprod. Sci. 2013, 141, 62-67. [CrossRef]

111. Drobnis, E.Z.; Nangia, A.K. Pain Medications and Male Reproduction. Adv. Exp. Med. Biol. 2017, 1034, 39-57. [CrossRef]

112. Sokolowska-Mikolajczyk, M.; Socha, M.; Mikolajczyk, T.; Chyb, J.; Epler, P. The effects of naltrexone, an opioid receptor antagonist, on plasma LH levels in common carp (Cyprinus carpio L.). Comp. Biochem. Physiol. Toxicol. Pharmacol. Cbp 2002, 131, 417-424. [CrossRef] 
113. Sokolowska-Mikolajczyk, M.; Socha, M.; Mikolajczyk, T.; Chyb, J.; Epler, P. Seasonal short-term effects of naltrexone on LH secretion in male carp (Cyprinus carpio L.). Comp. Biochem. Physiol. Toxicol. Pharmacol. Cbp 2002, 131, 379-385. [CrossRef]

114. Vijayalaxmi; Ganesh, C.B. Influence of leucine-enkephalin on pituitary-ovary axis of the cichlid fish Oreochromis mossambicus. Fish. Physiol. Biochem. 2017, 43, 1253-1264. [CrossRef]

115. López, F.J.; Merchenthaler, I.; Ching, M.; Wisniewski, M.G.; Negro-Vilar, A. Galanin: A hypothalamic-hypophysiotropic hormone modulating reproductive functions. Proc. Natl. Acad. Sci. USA 1991, 88, 4508-4512. [CrossRef]

116. Kim, D.K.; Yun, S.; Son, G.H.; Hwang, J.I.; Park, C.R.; Kim, J.I.; Kim, K.; Vaudry, H.; Seong, J.Y. Coevolution of the spexin/galanin/kisspeptin family: Spexin activates galanin receptor type II and III. Endocrinology 2014, 155, 1864-1873. [CrossRef] [PubMed]

117. Ohki-Hamazaki, H. Neuromedin B. Prog. Neurobiol. 2000, 62, 297-312. [CrossRef]

118. Ma, Z.; Su, J.; Guo, T.; Jin, M.; Li, X.; Lei, Z.; Hou, Y.; Li, X.; Jia, C.; Zhang, Z.; et al. Neuromedin B and Its Receptor: Gene Cloning, Tissue Distribution and Expression Levels of the Reproductive Axis in Pigs. PLoS ONE 2016, 11, e0151871. [CrossRef] [PubMed]

119. Culler, M.D.; Negro-Vilar, A. Pulsatile Follicle-Stimulating Hormone Secretion Is Independent of Luteinizing Hormone-Releasing Hormone (LHRH): Pulsatile Replacement of LHRH Bioactivity in LHRH-Immunoneutralized Rats. Endocrinology 1987, 120, 2011-2021. [CrossRef] [PubMed]

120. Pau, K.Y.F.; Gliessman, P.M.; Oyama, T.; Spies, H.G. Disruption of GnRH Pulses by Anti-GnRH Serum and Phentolamine Obliterates Pulsatile LH but not FSH Secretion in Ovariectomized Rabbits. Neuroendocrinology 1991, 53, 382-391. [CrossRef]

121. Padmanabhan, V.; McFadden, K.; Mauger, D.T.; Karsch, F.J.; Midgley, A.R., Jr. Neuroendocrine control of follicle-stimulating hormone (FSH) secretion. I. Direct evidence for separate episodic and basal components of FSH secretion. Endocrinology 1997, 138, 424-432. [CrossRef]

122. Padmanabhan, V.; Cardoso, R.C. Neuroendocrine, autocrine, and paracrine control of follicle-stimulating hormone secretion. Mol. Cell. Endocrinol. 2020, 500, 110632. [CrossRef]

123. Dickey, J.T.; Swanson, P. Effects of salmon gonadotropin-releasing hormone on follicle stimulating hormone secretion and subunit gene expression in coho salmon (Oncorhynchus kisutch). Gen. Comp. Endocrinol. 2000, 118, 436-449. [CrossRef] [PubMed]

124. Zhang, T.; Zhao, W.; Zhang, M.; Xu, B.; Shi, X.; Zhang, Q.; Guo, Y.; Xiao, J.; Chen, D.; Zheng, T.; et al. Analgesic activities of the mixed opioid and NPFF receptors agonist DN-9 in a mouse model of formalin-induced orofacial inflammatory pain. Peptides 2018, 110, 30-39. [CrossRef]

125. Lin, Y.T.; Chen, J.C. Neuropeptide FF modulates neuroendocrine and energy homeostasis through hypothalamic signaling. Chin. J. Physiol. 2019, 62, 47-52. [CrossRef]

126. Hu, K.L.; Chang, H.M.; Li, R.; Yu, Y.; Qiao, J. Regulation of LH secretion by RFRP-3-From the hypothalamus to the pituitary. Front. Neuroendocrinol. 2019, 52, 12-21. [CrossRef]

127. Schioth, H.B.; Watanobe, H. Melanocortins and reproduction. Brain Res. Brain Res. Rev. 2002, 38, 340-350. [CrossRef]

128. Wikberg, J.E.; Muceniece, R.; Mandrika, I.; Prusis, P.; Lindblom, J.; Post, C.; Skottner, A. New aspects on the melanocortins and their receptors. Pharmacol. Res. 2000, 42, 393-420. [CrossRef] [PubMed]

129. Dores, R.M.; Oberer, N.; Hoglin, B.; Thomas, A.; Faught, E.; Vijayan, M.M. Evaluating interactions between the melanocortin-5 receptor, MRAP1, and ACTH(1-24): A phylogenetic study. Gen. Comp. Endocrinol. 2020, 294, 113476. [CrossRef]

130. Morgan, C.; Cone, R.D. Melanocortin-5 receptor deficiency in mice blocks a novel pathway influencing pheromone-induced aggression. Behav. Genet. 2006, 36, 291-300. [CrossRef] [PubMed]

131. Metz, J.R.; Peters, J.J.; Flik, G. Molecular biology and physiology of the melanocortin system in fish: A review. Gen. Comp. Endocrinol. 2006, 148, 150-162. [CrossRef]

132. Meyer, R.C.; Giddens, M.M.; Coleman, B.M.; Hall, R.A. The protective role of prosaposin and its receptors in the nervous system. Brain Res. 2014, 1585, 1-12. [CrossRef] [PubMed]

133. van den Pol, A.N. Weighing the role of hypothalamic feeding neurotransmitters. Neuron 2003, 40, 1059-1061. [CrossRef]

134. Pinilla, L.; González, L.C.; Tena-Sempere, M.; Aguilar, E. Interactions between GABAergic and aminoacidergic pathways in the control of gonadotropin and GH secretion in pre-pubertal female rats. J. Endocrinol. Investig. 2002, 25, 96-100. [CrossRef]

135. Margeta-Mitrovic, M.; Jan, Y.N.; Jan, L.Y. Function of GB1 and GB2 subunits in G protein coupling of GABA(B) receptors. Proc. Natl. Acad. Sci. USA 2001, 98, 14649-14654. [CrossRef]

136. Göngrich, C.; García-González, D.; Le Magueresse, C.; Roth, L.C.; Watanabe, Y.; Burks, D.J.; Grinevich, V.; Monyer, H. Electrotonic Coupling in the Pituitary Supports the Hypothalamic-Pituitary-Gonadal Axis in a Sex Specific Manner. Front. Mol. Neurosci. 2016, 9, 65. [CrossRef]

137. Latorre, R.; Castillo, K.; Carrasquel-Ursulaez, W.; Sepulveda, R.V.; Gonzalez-Nilo, F.; Gonzalez, C.; Alvarez, O. Molecular Determinants of BK Channel Functional Diversity and Functioning. Physiol Rev. 2017, 97, 39-87. [CrossRef] [PubMed]

138. Contreras, G.F.; Neely, A.; Alvarez, O.; Gonzalez, C.; Latorre, R. Modulation of BK channel voltage gating by different auxiliary beta subunits. Proc. Natl. Acad. Sci. USA 2012, 109, 18991-18996. [CrossRef] [PubMed]

139. Walters, K.A.; Edwards, M.C.; Tesic, D.; Caldwell, A.S.L.; Jimenez, M.; Smith, J.T.; Handelsman, D.J. The Role of Central Androgen Receptor Actions in Regulating the Hypothalamic-Pituitary-Ovarian Axis. Neuroendocrinology 2018, 106, 389-400. [CrossRef]

140. Guzmán, J.M.; Luckenbach, J.A.; da Silva, D.A.M.; Hayman, E.S.; Ylitalo, G.M.; Goetz, F.W.; Swanson, P. Seasonal variation of pituitary gonadotropin subunit, brain-type aromatase and sex steroid receptor mRNAs, and plasma steroids during gametogenesis in wild sablefish. Comp. Biochem. Physiol. Part A Mol. Integr. Physiol. 2018, 219-220, 48-57. [CrossRef] 
141. Peñaranda, D.S.; Mazzeo, I.; Gallego, V.; Hildahl, J.; Nourizadeh-Lillabadi, R.; Pérez, L.; Weltzien, F.A.; Asturiano, J.F. The regulation of aromatase and androgen receptor expression during gonad development in male and female European eel. Reprod. Domest. Anim. 2014, 49, 512-521. [CrossRef]

142. Burmeister, S.S.; Kailasanath, V.; Fernald, R.D. Social dominance regulates androgen and estrogen receptor gene expression. Horm. Behav. 2007, 51, 164-170. [CrossRef] [PubMed]

143. Köves, K.; Szabó, E.; Kántor, O.; Heinzlmann, A.; Szabó, F.; Csáki, Á. Current State of Understanding of the Role of PACAP in the Hypothalamo-Hypophyseal Gonadotropin Functions of Mammals. Front. Endocrinol. 2020, 11, 88. [CrossRef] [PubMed]

144. Chang, J.P.; Johnson, J.D.; Sawisky, G.R.; Grey, C.L.; Mitchell, G.; Booth, M.; Volk, M.M.; Parks, S.K.; Thompson, E.; Goss, G.G.; et al. Signal transduction in multifactorial neuroendocrine control of gonadotropin secretion and synthesis in teleosts-studies on the goldfish model. Gen. Comp. Endocrinol. 2009, 161, 42-52. [CrossRef]

145. Gur, G.; Bonfil, D.; Safarian, H.; Naor, Z.; Yaron, Z. Pituitary adenylate cyclase activating polypeptide and neuropeptide $\mathrm{Y}$ regulation of gonadotropin subunit gene expression in tilapia: Role of PKC, PKA and ERK. Neuroendocrinology 2002, 75, 164-174. [CrossRef] [PubMed]

146. Hlubek, M.; Tian, D.; Stuenkel, E.L. Mechanism of alpha-latrotoxin action at nerve endings of neurohypophysis. Brain Res. 2003, 992, 30-42. [CrossRef] [PubMed]

147. Schindelin, J.; Arganda-Carreras, I.; Frise, E.; Kaynig, V.; Longair, M.; Pietzsch, T.; Preibisch, S.; Rueden, C.; Saalfeld, S.; Schmid, B.; et al. Fiji: An open-source platform for biological-image analysis. Nat. Methods 2012, 9, 676-682. [CrossRef]

148. Levavi-Sivan, B.; Yaron, Z. Involvement of cyclic adenosine monophosphate in the stimulation of gonadotropin secretion from the pituitary of the teleost fish, tilapia. Mol. Cell. Endocrinol. 1992, 85, 175-182. [CrossRef]

149. Dobin, A.; Davis, C.A.; Schlesinger, F.; Drenkow, J.; Zaleski, C.; Jha, S.; Batut, P.; Chaisson, M.; Gingeras, T.R. STAR: Ultrafast universal RNA-seq aligner. Bioinformatics 2013, 29, 15-21. [CrossRef]

150. Edgar, R.; Domrachev, M.; Lash, A.E. Gene Expression Omnibus: NCBI gene expression and hybridization array data repository. Nucleic Acids Res. 2002, 30, 207-210. [CrossRef]

151. Barrett, T.; Wilhite, S.E.; Ledoux, P.; Evangelista, C.; Kim, I.F.; Tomashevsky, M.; Marshall, K.A.; Phillippy, K.H.; Sherman, P.M.; Holko, M. NCBI GEO: Archive for functional genomics data sets-update. Nucleic Acids Res. 2012, 41, D991-D995. [CrossRef] [PubMed]

152. Suzuki, S.; Ishida, T.; Ohue, M.; Kakuta, M.; Akiyama, Y. GHOSTX: A Fast Sequence Homology Search Tool for Functional Annotation of Metagenomic Data. Methods Mol. Biol. 2017, 1611, 15-25. [CrossRef] [PubMed]

153. Raudvere, U.; Kolberg, L.; Kuzmin, I.; Arak, T.; Adler, P.; Peterson, H.; Vilo, J. g:Profiler: A web server for functional enrichment analysis and conversions of gene lists (2019 update). Nucleic Acids Res. 2019, 47, W191-W198. [CrossRef]

154. Hollander-Cohen, L.; Böhm, B.; Hausken, K.; Levavi-Sivan, B. Ontogeny of the specificity of gonadotropin receptors and gene expression in carp. Endocr. Connect. 2019, 8, 1433-1446. [CrossRef] [PubMed]

155. Kanehisa, M.; Furumichi, M.; Tanabe, M.; Sato, Y.; Morishima, K. KEGG: New perspectives on genomes, pathways, diseases and drugs. Nucleic Acids Res. 2017, 45, D353-D361. [CrossRef] 